\title{
ICT enabled Almajiri education in Nigeria: Challenges and prospects
}

\author{
AbdulGafar Olawale Fahm ${ }^{1}$ - Adesina Lukuman Azeez ${ }^{2}$. \\ Yusuf Olayinka Imam-Fulani ${ }^{3}$. Omenogo Veronica Mejabi ${ }^{4} \cdot$ Nasir Faruk $^{3}$. \\ Musbau Dogo Abdulrahaman ${ }^{4}$. Lukman Abiodun Olawoyin ${ }^{3}$. \\ Abdulkarim Ayopo Oloyede ${ }^{3} \cdot$ Nazmat Toyin Surajudeen-Bakinde $^{5}$
}

Received: 26 November 2020 / Accepted: 4 March 2021 / Published online: 13 September 2021 (c) The Author(s), under exclusive licence to Springer Science+Business Media, LLC, part of Springer Nature 2021

\begin{abstract}
The Almajiri children in Nigeria are deserving of special interventions to reduce the life-long divide in educational achievement, social status, and economic empowerment. One way of speedily achieving this is through the use of Information and Communication Technologies (ICTs). This study examined the prospects and challenges of using ICT in the teaching and learning processes of Almajiri children's education in Nigeria. A descriptive research methodology was adopted and data were collected from the Almajiri children, their teachers, and parents from communities with a high concentration of Almajiri schools. The results showed that while the official language of instruction in schools in Nigeria is English, the language often spoken by children and teachers was Hausa. Also, while teachers and parents were quite familiar with ICTs such as mobile phones, computers, and television, the Almajiri children were more familiar with television and mobile phones, and very few had used a computer. Some strategies proposed for successful adoption of ICT in Almajiri education include the use of indigenous languages in courseware development and the use of one-to-many ICT facilities, such as multimedia teaching aids, projectors, and smart televisions.
\end{abstract}

Keywords Cultural and social implications · Early years education · Information literacy $\cdot$ Learning communities $\cdot$ Teaching/learning strategies

AbdulGafar Olawale Fahm

fahm.ao@unilorin.edu.ng

1 Department of Religions, Faculty of Arts, University of Ilorin, Ilorin, Nigeria

2 Department of Mass Communication, University of Ilorin, Ilorin, Nigeria

3 Department of Telecommunication Science, University of Ilorin, Ilorin, Nigeria

4 Department of Information and Communication Science, University of Ilorin, Ilorin, Nigeria

5 Department of Electrical and Electronics Engineering, University of Ilorin, Ilorin, Nigeria 


\section{Introduction}

The importance of education in an individual's life is sacrosanct in achieving an organised society. Thus, the orderliness and stability of society are predicated on the premium placed on its educational system. This is why the philosophy of education emphasizes the pursuit of rational as well as the moral development of humans that will ultimately lead to the betterment of society. This is, indeed, the "justifiable aims" of education (Ogeno, 1993).

It has been rightfully established in Article 24 of the 1948 Universal Declaration of Human Rights, that "everyone has the right to education". Globally, one of the indices of the Sustainable Development Goals (SDGs) is the provision of "quality education", and it is ranked as number four in the "Envision 2030" document (UN, 2015). Thus, the Federal Republic of Nigeria has also incorporated the right to education in its 1999 Constitution with an emphasis that "Government shall direct its policy towards ensuring that there are equal and adequate educational opportunities" for all and sundry.

To achieve the objective of providing equal and adequate educational opportunities, the government in Nigeria has made several attempts to grant and expand access to education. The attempts include the implementation of the 2004 education policy, which underscores the right of every Nigerian child to have full access to quality education (FRN, 2004). The access, according to the policy, "is to make it possible for everyone who is entitled to education to receive it". In pursuance of this policy, primary education is made free and compulsory in many states of Nigeria; and up to the secondary school level in many others.

Essentially, nomadic and Almajiri education systems were integrated into the mainstream of the Universal Basic Education (UBE). This is to address the inequities in accessing primary education (FME, 1986), and to eliminate the apparent exclusion being suffered by many children in the Northern part of the country. Indeed, many northern states are regarded as "educationally disadvantaged" (Agile, 2018); the tag which, according to Moti (2010), has been posing a perennial challenge since the introduction of the western education system in Nigeria.

The Almajiri educational system is also aimed at addressing the rising number of out-of-school children, which is now more than 13 million, with ten northern states accounting for eight million of those children (Adedigba, 2019). Therefore, Almajiri education is a special intervention to stem the tide of the lingering menace of Almajiri culture or syndrome in Northern Nigeria that is now being rightly described as a" time bomb" (David, 2019). It is a special education system that is designed to provide quality and accessible education for all categories of children including orphans, children from the low-income earning family, children from the socio-economic and ethnic minorities, and children from broken homes (Agile, 2018) in the northern states of Nigeria. Its introduction is to cater to the educational needs of over 9.5 million Almajiri children who accounted for 72 percent of Nigeria's 13.2 million out-of-school children (UNICEF, 2014). It is, therefore, a strategy for achieving what Ogeno (1993) called a "justifiable aim". It is to enforce the Nigerian Child Right Act, which enjoins that: "Education is the birth right of every Nigerian child, and should be brought close to the environment of 
the child" (FME, 1986). As it is entrenched in the Act that established the Almajiri education, signed into law in 2012, the main objective of the Almajiri schools is to "ensure that Almajiris are provided with opportunities for access to Basic Education" (Taiwo, 2013). Almajiri is a Hausa Language word derived from Arabic "Al muhajirun" referring to a person who migrates from his home in search of Islamic knowledge (Yusha'u et al., 2013). Due to the neglect and lack of supportive care, the Almajiris end up begging for survival; hence, the term "Almajiri" has been further expanded to refer to as any young person who begs on the street. However, in this paper, we refer to Almajiris as the children who left their various homes to learn the Quran and seek knowledge of Islam from teachers, who are versed in the knowledge, but are abandoned by their parents. As such, they resort to the street begging for alms and survival because of lack of adequate care (Aghedo \& Eke, 2013). Of course, the concept of Almajiris has also been misunderstood to refer to the young street beggars, and children who engage in menial jobs (Magashi, 2015).

Thus, the Almajiri education system is an integration of western education with the traditional Quranic School systems without interfering with the goals of the latter. It is a special education system, which aims at strengthening the ability of the learners to read, write, and memorise the Qur'an in conducive learning environments. At the same time, it aims at introducing secular subjects of education into Qur'anic school system to make the products of the system literate, numerate, and skilful as a way of meeting the goals of Education For All (EFA). In other words, it incorporates elements of basic education (literacy, numeracy, and life skills of the western type of education) into the traditional Qur'anic school system through certain strategic frameworks (UBEC, 2013).

Many state governments in Northern Nigeria had, indeed, begun the operation of the Almajiri education system, adopting different models to achieve its objectives. For instance, about 117 Model One Almajiri schools that integrate western education with Quranic education are in operation across 26 states of the federation and the Federal Capital Territory (FCT). Also, 138 schools in 30 states and the FCT are already adopting Model III of the Almajiri system, retaining the Islamiyya and Arabic training in a more formal environment provided through government intervention funds (UBEC, 2013).

\section{Problem statement}

Although the social intervention programme, such as the school feeding programme by the federal government of Nigeria has been reportedly yielding result as there is an increase in the school enrolments (Taylor \& Ogbogu, 2016), there is not yet reliable evidence of the success of the Almajiri education in the delivery of its learning objectives and outcomes. There is a wide range of assumptions as to why quality learning and outcomes are not yet evidenced in the Almajiri education system. Some argued that the system is alien to the target students (Shuaibu \& Jimoh, 2011; Ya'u, 2001), while some other scholars blamed the ineffective delivery of its curriculum 
(Oladosu, 2012; Yusha'u et al., 2013), especially with the use of ICT in teaching and learning processes.

The affordance nature of ICTs such as social media tools, indeed, makes them quintessential of the learning environment. The invention of communicative tools such as Skype and Zoom has the potential to revolutionise the learning experience of pupils (Carr \& Hayes, 2015). In addition, ICT has shown that with the adoption of necessary technology, learning can be an enjoyable experience. For example, social media teleconferencing and video-telephony would eliminate physical barriers posed by the distance between teachers and learners (Lau et al., 2011).

Furthermore, a lot of instructional materials can be delivered audio-visually. Studies have shown that ICT facilitates improved interactive and educative online environment for the pupils, enables greater levels of remote learning, and brings inclusion of students into a "live contact" with teachers through e-mail, chat sessions, e-learning, web-based learning including internet, intranet, extranet, CDROM, television and audio-video tape (Sharma et al., 2011; Sangra \& GonzalezSanmamed, 2016; van Brakel \& Chisenga, 2003). In education, ICT has been proven to have the capacity for providing many opportunities for involvement, promoted by user-defined preferences, active object manipulation, real-time events, multiple representations of data, intelligent responses, and participation in games and communities-all of which can improve the learning outcome of pupils (Westera, 2004).

Taking the problem of curriculum delivery as a more plausible reason, this study explored the use and significance of ICTs in the effective delivery of the Almajiri curriculum with the main purpose of determining the extent to which ICT can be used to enhance teaching and learning in Almajiri schools and recommending strategies for its effective use in bringing about quality learning in the system. To this end, the study endeavoured to answer the following questions:

1. Which ICT devices are most recognizable and utilized by the different stakeholders (pupils, teachers, parents)?

2. How do the stakeholders perceive the use of ICT for teaching and learning in Almajiri schools and is there any effect of gender on this?

3. What challenges do stakeholders envisage in the use of ICT in Almajiri schools?

4. Which ICT device(s) are currently being used in the Almajiri schools?

5. What outcomes and what strategies for success can be recommended in the use of ICT for teaching and learning in Almajiri schools?

\section{Educational situation of the Almajiri schools: The connection between public and Islamic education systems}

Almajiri is a system of Islamic education practiced in northern Nigeria. It is an ageold tradition where parents send their children, mostly boys, to distant locations to acquire Qur'anic education. Many never received a formal education. Instead, they spent their formative years in traditional Islamic education memorizing the Qur'an. Under this educational system, many rural and poor families who cannot afford formal schooling have made this choice with the belief that they are fulfilling their 
obligation to provide a religious and moral education to their children and that the learning is provided free of charge.

The system was enthusiastically supported by all stakeholders in the education enterprise, which enabled it to record unprecedented success in the pre-colonial period. For instance, Ajayi and Oloruntimehin (1976, p. 78) observed that "It should be emphasised that majority of West Africans in the first three quarters of the nineteenth century Islam, not the Christian abolitionist movement, was the revolutionary factor creating larger political with new economic opportunities and establishing new religious obligations and social values". According to Clarke (1978), "[i] $\mathrm{n}$ Kano fifteenth century there were an estimated three thousand mallams. Teaching and learning were by lectio and memoriter (reading aloud and rote memorisation). With time the peripatetic system gave way, never completely, to a formalised, institutionalised Qu'ranic education" (p. 134).

Hence, for many centuries there existed in northern Nigeria an educational system considered by many to be largely acceptable. Thus, the introduction of a western system of education was not without a challenge. In the colonial era, western system of education was regarded by Muslims to be culturally and religiously unproductive. The arrival of the colonial rule affected the northern Islamic education scheme, its supporters as well as admirers. Islamic education became less and less a concern of the government and mainly left in private hands.

Almajiri system of education being a traditional and non-formal system of education is today faced with various challenges and they are not unrelated to funding and the level of support received by drivers of the system in contemporary period. That is why there are calls for more integrative and comprehensive system of learning that combines the western or the public system of education in the country as well as Islamic system of education.

\section{Literature review}

The relevance of ICT in combatting the scourge among one of the most vulnerable groups in society has been explored (Ibrahim \& Sanda, 2019; Ibrahim et al., 2019). In Nigeria, Almajiris are considered a vulnerable group because they often abandon the Quranic schools to beg for alms all the time and are highly disadvantaged in access to formal education. The Nigerian government in responding to this problem established the National Commission for Nomadic Education in 1989. The Commission was saddled with the responsibilities of providing quality basic education for nomads (which also include the Almajiris or itinerant pupils), boosting their literacy capacity, and equipping them with skills and competencies to enhance their well-being and participation in national development and integration. The approach taken by the Commission in addressing these responsibilities includes the provision of infrastructural facilities, mobile schools/mobile classrooms, provision of boat schools and dug-out canoes, radio and television education, provision of extension services, and linkage with local, national, and international bodies (Olaniran, 2013). However, the Almajiris have continued to encounter low overall literacy rates. While the number of illiterate persons has 
fallen over the past decade in the country as a whole, many Almajiris who are concentrated in the northern region of Nigeria still lack basic Western reading and writing skills.

Connected to today's educational institutions is technology. Undoubtedly, computer usage is associated with 21st-century teaching and learning (Cartelli, 2013). According to Adu and Olatundun (2013), the use of ICTs in education has the potential of innovating, accelerating, enriching, and deepening skills, thereby motivating and engaging students in relating school experiences to work practices which assist in creating economic viability for tomorrow's workers, as well as strengthening teaching and helping schools change (Kennedy et al., 2008; Streatfield \& Markless, 2008). That is why ICT is being considered as an option for improving the education of the Almajiri in Nigeria as part of the need for the state to provide meaningful education that takes into account contemporary teaching and learning deliveries (Okugbeni, 2013). In furtherance to this, Fernández-Gutiérrez et al. (2020), evaluated whether regions in Spain that further increased ICT at schools achieved higher improvements in students' outcomes. Findings from the work show high use of ICT at school has a positive effect on outcomes.

Moreover, the demand for education in Africa has been on the increase. Therefore, there is a need to improve people's access to learning. Besides, a technology which is one of the commonest means of communication plays a pivotal role in extending the possibilities for teaching and learning in educational institutions (Kabir \& Kadage, 2017). Numerous studies, for instance, have shown success stories of ICT teaching and learning in the developed world (Addo, 2001; Guemide \& Benachaiba, 2012; Hong \& Songan, 2011).

Olatunji et al. (2016) speak to the delicate nature of ICTs and young minds when they observe that "technologies play important roles in children lives who are residents in the digital era and could proactively operate and share information on rights and privileges, and to the reality of receiving guidance and protection from secular authority against abuse and forced labour". Also, Odumosu et al. (2013, p.37) note that part of the major challenges faced by the Almajiri system of education is the "lack of integration into the formal education, standardization, certification, remuneration, monitoring of the Quranic schools and their teachers (Mallams) or operators constitute a serious setback to the products having lost the opportunity of receiving adequate literacy skills to function effectively in a rapidly changing world of technological innovations and opportunities".

In addressing how ICT has been used in educating or changing children's lives positively or negatively, Drigas et al. (2015) in their study present an overview of studies between 2003-2014 which concentrates on collaborative co-learning and other ICT applications in kindergarten children who face memory difficulties. They also examined the effectiveness of ICT in maths and in children who face learning difficulties as well as the effectiveness of a collaborative intervention and diagnostic tools for children with poor working memory. In concluding their study, they pointed out that certain technological breakthroughs can be noticed in several kinds of research that focus on the support of children with such deficits. Al-Huneini et al. (2020) investigated the introduction of touchscreen tablet computers into rural primary schools in Oman. The 
study found that the tablets changed the working culture of staff in the project and the behaviour and responsibilities of the pupils.

Today, many researchers are convinced that ICT in early childhood education provides multiple possibilities for young children (Kerckaert et al., 2015; Plowman \& Stephen, 2003; Selwyn \& Bullon, 2000). That is why many early childhood educators feel positive about using ICT with children. Also, it is believed that ICT and electronic gadgets can enhance and improve students' learning process as well as provide better teaching methods (Sangra \& Gonzalez-Sanmamed, 2016; Leung, 2011; Saruji et al., 2017).

Ciccarelli et al. (2015) examined the health implication of children using mobile ICT at home. They focused on postures during ICT use and on musculoskeletal complaints. The study concluded that unconventional postures adopted by children in the home are questionable, hence can have negative repercussions (Ciccarelli et al., 2015). In addition, many children with disabilities are often segregated and ICT has been highlighted as a tool for communication and inclusion for children with disabilities.

It is worth noting that educators, researchers, and thinkers have taken up the challenges of using ICT since the 1980s with varied success. The advent of the internet and the World Wide Web has pressured new productivity and service demands as well as expectations (Carmona \& Marin, 2013; Cox \& Marshall, 2007; Melor et al., 2009). For instance, in a paper that investigated teachers' and educational consultants' perceptions of ICT integration in Québec English Schools, specifically with regard to the benefits and challenges of ICT integration therein. Results revealed higher student engagement levels and enhancement of the learning process as the main benefits of integrating ICT in English Québec Schools. The following challenges were also highlighted: lack of supporting school leadership, inconsistent investments in ICT equipment, infrastructure and resources, the inflexibility of funding, the need for additional professional development and support, and incorporation of technology in evaluations and curricular plans (Rabah, 2015).

Researchers have also attempted to address the factors affecting the successful implementation of ICT in schools. Some of the results showed that ICT was perceived as an important tool in improving performance, collaboration, learning experience, and learning outcomes. However, some challenges that affect the application of ICT are, for example, the lack of space, resources, maintenance, a lack of ICT skills among school along with a lack of ICT training and a lack of clear ICT policies. Personal factors therein also contributed to the challenges. There exist some levels of prevalence of teachers' personal factors over contextual ones. Gender and age were also determining factors of teachers' digital competence, followed by ease of use, confidence in using digital technology, and openness to new technology. However, the overcoming of these obstacles could turn these barriers into positive factors to aid in the success of ICT implementation (Albugami \& Ahmed, 2015; Ali \& Proctor, 2005; Mdlongwa, 2012). This could be achieved through strategic and practical professional training (Ifinedo et al., 2020). Besides, authors have also argued that school leadership determines how ICT is implemented and its subsequent impact on teaching and learning. This involves the Principal as a school leader to lead in 
implementation. A positive attitude of school leaders towards the implementation of ICT will encourage the school community to be actively involved in its implementation. However, many challenges hinder effective ICT implementation including school leadership challenges. That is why there have been recommendations besides sensitizing development partners and waiting for their contributions, school leadership should consider ICT a priority in school and allocate budgets that would promote its implementation (Mingaine, 2013).

\section{Theoretical framework}

With the recent increase in the development of ICT tools for use in education and coupled with its integration into virtually every aspect of human life, a decision concerning its acceptance or rejection by users remains an open question. Several researchers had formulated many theories concerning the adoption, perception, acceptance, infusions, and ease-of-use of ICT in the education process. These theories include: the Diffusion of Innovation theory (DOI); Social Cognitive Theory (SCT); Theory of Reasoned Action (TRA); Theory of Planned Behavior (TPB); Technology Acceptance Model (TAM) among others (Rogers, 1999; Scurry et al., 2005; Venkatesh \& Davis, 2000; Mun et al., 2006). Out of many of these theories propounded, the TAM and the Unified Theory of Acceptance and Use of Technology (UTAUT) are the most dominant and recent models for the investigation of the factor affecting users' acceptance or rejection of ICT in education (Ling et al., 2011).

TAM which was developed by Davis et al. (1989) as an improvement of TRA considers Attitude (A) and Behavioral Intention (BI) to measure technology acceptance in the ICT domain. This model was developed by adopting Fishbein and Ajzen's (1975) Theory of Reasoned Action (TRA) which explains the person's behavior as a combination of personal attitude and subjective norm. TAM established that two particular beliefs "Perceived Usefulness" $(P U)$, and "Perceived Ease of Use" $(P E U)$ are key determinants of technology acceptance or rejection of ICT. $P U$ is the expectation of a user that the use of an ICT tool will improve his performance on a specific job while $P E U$ deals with the perception of a user that using an ICT tool will be stress-free (Marangunić \& Granić, 2015; Jain et al., 2016; Ammenwerth, 2019). These two beliefs are then used to determine the user's Attitude (A) towards using the tool, which is in turn used to determine Behavioural Intention to use (BI). The BI is then used to determine the actual usage of the system (U).

Based on the fact that TAM ignores some important social factors that scan equally affect the perceived user's acceptance or rejection of ICT, Venkatesh et al. (2003) introduced a more veritable review of TAM known as The Unified Theory of Acceptance and Use of Technology (UTAUT). UTAUT identifies four constructs and four moderating variables rather than the two key variables of TAM.

The four constructs that were identified as the main determinants of whether or not a user will accept, use and adopt an ICT for a purpose are Performance Expectancy $(P E x)$, Effort Expectancy (EEx), Social Influence (SI), and Facilitating 
Conditions (FC). PEx means the gain in job performance attained by a user due to the use of ICT. EEx is defined as the user's perception of the amount of ease involved in using a particular ICT tool. SI is related to the social perceptions associated with using ICT while $F C$ means the perception of an individual towards the availability of the technical aspects and infrastructure that can assist in the use of an information system. Gender, age, experience, and voluntary use were listed as the moderating factors that can affect the four constructs identified in UTAUT.

In UTAUT, PEx, EEx, and SI are used to determine the behavioural intention (BI) of a user to make use of the technology. The Actual usage of the technology (A) can be determined with BI and FC while the four moderating factors have a direct effect on the impact of BI and use behaviour (Ammenwerth, 2019).

For this research, the TAM and UTAUT models provide a basis for investigating the place of ICTs in Almajiri education, while examining the effect of moderating factors such as gender, age, and experience, which are key components of interest.

\section{Methodology}

The study used a descriptive methodology by applying a survey design to achieve the aim of the research. The study focused on Niger state which is the largest in the landmass of the 36 states in Nigeria. It is located in the North Central zone of Nigeria and has a high concentration of Almajiri children just like any of the Northern states of Nigeria. Niger state consists of 25 local government areas (LGAs) distributed across three senatorial districts. This state was chosen because it is a northern state which is centrally located in Nigeria.

It should be noted that the Almajiri school system was designed exclusively for boys (Fafunwa, 1974), and is characterised by parents taking their children to far places, usually to the big cities, and handing them over to teachers (mallams) to obtain knowledge rooted in Islam (Suleiman, 1990) leading to the schools also being described as Quranic schools.

In pursuing the policy of integrating the Almajiris into the formal school system, three models classified as Model I, Model II, and Model III, have been identified by the Universal Basic Education Commission (UBEC) (UBEC, 2013). The school models are described as follows:

Model I schools - established to integrate traditional Quranic schools into the formal education system within their initial locations. There are 117 schools across 26 states and the FCT.

Model II schools - these are Islamiyyah and Tahfeez schools supported by the government to provide boarding facilities to benefit Quranic schools within a specific location in the respective states of Nigeria. There are 36 schools constructed across Nigeria.

Model III schools - are already existing Islamiyyah and Arabic schools supported with funds for rehabilitation of their infrastructure. There are 138 schools in 30 states and the FCT. 
Apart from the model schools described, several Almajiri schools do not receive any government support, which is informal. In this study, these are described as unsupported schools.

The population considered for the study were the unsupported Alamjiri schools and those in government-supported schools (i.e. the model I, model II, and model III schools). Teachers at these schools and parents in households in the communities where the unsupported schools are located were also part of the study. Thus, the study population comprised of three groups:

i. Pupils in the Almajiri schools in Niger State, Nigeria.

ii. Teachers in the Almajiri schools in Niger State, Nigeria.

iii. Parents of school-age children in Niger State, Nigeria.

The sampling design adopted for the study used a purposive sample from one major town in each senatorial district, where such towns have a presence of any of the three models of government-supported Almajiri schools and there is also the presence of unsupported Almajiri schools in the immediate neighbouring communities. The towns selected were Minna (from Niger north senatorial district), Bida (Niger central senatorial district), and Zungeru (Niger west senatorial district). These towns were the focal point around which the sampling was designed. Thus, based on the sampling design, the pre-field samples were proposed as 198 Almajiri children, 57 Teachers, and 54 parents.

Data were collected using the researchers administered questionnaires that were designed based on the key components of the TAM and the Unified Theory of Acceptance and Use of Technology (UTAUT) model. In operationalizing the relevant components of the TAM / UTUAT models, the questionnaire items were intended to identify respondents' familiarity with the IT devices and did not distinguish between personal or classroom use. Each participating group had a questionnaire specific to that group. Since our respondents consisted of both educated and uneducated audience, to ease the task, we employed the use of close-ended questions, which required simple 'Yes' or 'No' response as well as few openended questions, which gave respondents freedom of expression. Our open-ended questions were designed in line with questionnaire-design guidelines proposed in Ajzen and Fishbein (1980) while close-ended questions followed principles of salient beliefs. The respondents were classified into three groups (children, teachers and parents) and each participating group had a questionnaire specific to it.

The questionnaire for children had two sections - background details and familiarity with ICTs. The section on background details included items such as gender, age, class in school, home town, state of origin, language(s) spoken by a child,. The section on familiarity with ICTs had questions focused on computers, mobile phones, and television and started with asking the child to identify the device from a sheet with pictures of computers, cameras, mobile phones, televisions, and radios. An open ended question was used to elicit what the child used the device for. 
The questionnaire for teachers also consisted of participant consent section and four other major sections. These were; Background of the respondent; Frequency of use of ICT devices; and Ease of use of ICT devices. The last two sections used a 4-point Likert scale of "very often" to "never" and "very easy" to "very difficult" to characterize the respondents frequency of use of ICT devices; and ease of use of ICT devices, respectively. A battery of twelve statements measured with 5-point Likert scale of "strongly agree" to "strongly disagree", were used to elicit teachers" opinions on the use of ICTs for teaching and learning.

The questionnaire for the parents followed a similar arrangement with the teachers', starting with background details such as gender, age, and educational level, then familiarity with ICTs, and opinion on its use by children. This last section also focused on characterizing the respondents frequency of use of ICT devices; and ease of use of ICT devices such as computers, mobile phones, and television.fA pilot test was done in July, 2019, to validate the questionnaires after which they were updated. The questionnaires were administered by the researchers simultaneously across the three towns from 27-31 August, 2019. The researchers worked with translators to aid communication with the respondents. Consent was obtained from the head teacher before pupils in the school were interviewed. The purpose of the research was explained to the children and they were informed that they could stop participating at any time if they so wished. Informed consent was also obtained from the teachers and parents before the questionnaire was administered.

Analysis of the data collected was done by using descriptive statistics such as frequency, cross-tabulation, and independent t-test to test hypotheses.q1.

\section{Results}

A total number of 300 questionnaires were distributed to three categories of respondents representing the key stakeholders in the Almajiri education systempupils, teachers, and parents. At the end of the data collection, the number of useable questionnaires was 164 from the pupils, 39 from teachers, and 41 from parents, totalling 244 . This represents a $95 \%$ response rate.

\subsection{Background of respondents}

The background of the respondents described by their gender, age group, level of education, and the languages spoken are presented in this section. The gender distribution of respondents is shown in Table 1. Out of the 164 pupils that were sampled, $105(64 \%)$ were male, while 59 (36\%) were female. Similarly, $34(87.2 \%)$ of the 39 teachers that participated in this study were male and $5(12.8 \%)$ of them were female. Of the 41 parents that were also captured in this study, $87.8 \%$ were male while the remaining $12.2 \%$ were female. The number of female respondents was this low for all the population groups involved in this study (children, teachers, parents) 
because of the religious and cultural practice in the study area. In the north-central part of Nigeria, free interaction with women or girls is not encouraged.

A majority of the pupils involved in this study were between six and nine years of age (53.7\%) as shown in Table 2. None was below the age of six as none of the children in the Almajiri school system began their primary education at an age lower than six years. The results in Table 3 also show that a majority of the teachers and parents in the sample were aged between 25 to 50 years $-52 \%$ of the teachers and $71 \%$ of parents.

The educational level of the respondents is presented in Tables 4 and 5. The Table 4 shows that about $40 \%$ of the pupils involved in this study were in primary six. Meanwhile, 33 of the sampled pupils, representing 20.1\%, were in primary $4 ; 19(11.6 \%)$ in primary $5 ; 15(9.2 \%)$ in primary 3 and $32(19.5 \%)$ in Qur'anic class.

Table 5 shows that 17 (43.6\%) of the total sampled 39 teachers had tertiary education ranging from the National Teachers Certificate to University degrees. A substantial number of the sampled teachers (38.5\%) had secondary education, which is below the standard qualification for teaching in primary school. Also, surprisingly, 7 (17.9\%) of the sampled teachers had primary education, which is well below the minimum acceptable standard for teaching in primary schools in Nigeria.

Respondents were asked to indicate the languages they often use in school, and the results are shown in Table 6. Notably, the most common language, which pupils and teachers speak and use for teaching and learning, is Hausa. Amongst children, $73.8 \%$, speak Hausa while among teachers the proportion is $76.9 \%$ that speak Hausa. Other indigenous languages that are also spoken by pupils and teachers are Nupe and Gwari. Additionally, 20\% of the pupils sampled and $59 \%$ of the teachers can speak Arabic language. Less than half (49.4\%) of the pupils can speak English compared to a majority of the sampled teachers (76.9\%). Thus, there is a multiplicity of languages spoken and used in school.

\subsection{Respondents' familiarity with ICTs}

One of the research questions has to do with familiarity with ICTs. It is important to identify this to have a baseline from where to launch the use of ICT in teaching and learning among the stakeholders in the Almajiri school system. Results from each stakeholder group are presented in the following sections.

Table 1 Gender of respondents

\begin{tabular}{|c|c|c|c|c|c|c|}
\hline \multirow[t]{2}{*}{ Sex } & \multicolumn{2}{|l|}{ Children } & \multicolumn{2}{|l|}{ Teachers } & \multicolumn{2}{|l|}{ Parents } \\
\hline & Frequency & $\%$ & Frequency & $\%$ & Frequency & $\%$ \\
\hline Male & 105 & 64.0 & 34 & 87.2 & 36 & 87.8 \\
\hline Female & 59 & 36.0 & 5 & 12.8 & 5 & 12.2 \\
\hline Total (N) & 164 & 100.0 & 39 & 100.0 & 41 & 100.0 \\
\hline
\end{tabular}


Table 2 Age group of children in the sample

\begin{tabular}{llr}
\hline Age group (in years) & Frequency & \multicolumn{1}{c}{$\%$} \\
\hline Below 6 & 5 & 3.0 \\
$6-9$ & 88 & 53.7 \\
$10-12$ & 39 & 23.8 \\
$13-15$ & 20 & 12.2 \\
$16-18$ & 3 & 1.8 \\
Above 18 & 1 & 0.6 \\
No response & 8 & 4.9 \\
Total (N) & $\mathbf{1 6 4}$ & $\mathbf{1 0 0 . 0}$ \\
\hline
\end{tabular}

\subsubsection{Children's familiarity with ICTs}

Pupils were asked various questions about their familiarity and use of computers, mobile phones, and television. Such questions included confirmation of use, ease of use, frequency of use, and willingness to use ICT for learning. The results are presented in Table 7.

The results in Table 7 reveal that a large proportion of children ( $70 \%$ or more) could identify all three ICT devices; a higher number identified the television set $(81 \%)$, followed by the mobile phone $(75 \%)$ which was more than those that could identify the computer $(71 \%)$. These results are reflective of the pervasiveness of each of the different ICT devices in society. While a majority of the sampled children $(60.4 \%)$ confirmed they had never used a computer for learning, a large majority (77.4\%) of them confirmed that they had seen and learnt through television. Equally, a good number of the students $(54.9 \%)$ confirmed that they used and had learnt through mobile phones.

Reasons why the pupils had rarely used a computer for learning is deduced from their perception about the easiness of using each of the ICT devices they had identified to be familiar with. Fifty-seven of the students, representing $34.8 \%$, perceived the use of a computer to be "very difficult" while 15 of them, representing $9.1 \%$, said computer is "very easy" to use, although a large majority of the

Table 3 Age group of teachers and parents in the sample

\begin{tabular}{lllllr}
\hline Age group (in years) & \multicolumn{2}{l}{ Teachers } & & & Parents \\
\cline { 2 - 3 } \cline { 6 - 6 } \cline { 6 - 6 } & Frequency & $\%$ & & Frequency & $\%$ \\
\hline Less than 25 & 6 & 15.4 & 7 & 17.1 \\
$25-30$ & 11 & 28.2 & 13 & 31.7 \\
$31-40$ & 14 & 35.9 & 7 & 17.1 \\
$41-50$ & 7 & 17.9 & 9 & 22.0 \\
$51-60$ & - & - & 3 & 7.3 \\
Above 60 & 1 & 2.6 & - & - \\
No response & - & - & 2 & 4.9 \\
Total (N) & $\mathbf{3 9}$ & $\mathbf{1 0 0 . 0}$ & $\mathbf{4 1}$ & $\mathbf{1 0 0 . 0}$ \\
\hline
\end{tabular}


Table 4 Education level of children

\begin{tabular}{lllr}
\hline S/No. & Equivalent class & \multicolumn{2}{l}{ Children } \\
\cline { 3 - 4 } & & Frequency & $\%$ \\
\hline 1 & Primary 3 & 15 & 9.2 \\
2 & Primary 4 & 33 & 20.1 \\
3 & Primary 5 & 19 & 11.6 \\
4 & Primary 6 & 65 & 39.6 \\
5 & Qur'anic class & 32 & 19.5 \\
& Total (N) & $\mathbf{1 6 4}$ & $\mathbf{1 0 0 . 0}$ \\
\hline
\end{tabular}

students (92), equivalent to $56.1 \%$, did not give any response in respect of how easy they found the use of computer for learning purposes. On the other hand, a large proportion $(77.4 \%)$ perceived television to be very easy to use for learning and $79(48.2 \%)$ also said mobile phone is similarly very easy to use.

Their perception about the ease of use or otherwise of each of the ICT devices identified supports or explains the frequency of using each of the devices by the students. Thus, while 105 (64\%) of the students did not give a response to how frequent they use a computer, only $27(16.5 \%)$ said they used it weekly and $8(4.9 \%)$ of the students used the computer once in a year, explaining why a majority perceived it to be very difficult to use. On the other hand, 60 (36.6\%) watched and used television for learning every week while $62(37.8 \%)$ watched and used television many times in a year. Only a small percentage of $3.7 \%$ said they watched and used television once a year. Meanwhile, nearly half of the students noted that they would be happy to use each of the identified ICT devices as part of their daily or normal lessons (47.0\% for computer; $44.5 \%$ for mobile phone and $55.5 \%$ for television.

An open-ended question was used to obtain information on what the child did with the various ICT devices. Their responses are categorised and summarised in Table 8. The table reveals that there are several ways that the students who responded to this question in the Almajiri system use the identified ICT devices. For instance, most of the children (20\%) that indicated what they used television for, used it "to watch film, play games and listen to music". They also used the television for "listening to preaching and Islamic lectures"; and "to access information and news" (10\% of the children in each case). On what they used the mobile phone for, many children (13\%) indicated that they used it for "sending messages, receiving call, browsing, and downloading information". Six percent (6\%) of the children said they used the mobile phone also "to watch film, play games and listen

Table 5 Education level of teachers and parents in the study

\begin{tabular}{llllll}
\hline Highest qualification & \multicolumn{2}{l}{ Teachers } & & \multicolumn{2}{l}{ Parents } \\
\cline { 2 - 3 } & Frequency & $\%$ & & Frequency & $\%$ \\
\hline Primary & 7 & 17.9 & 10 & 24.4 \\
Secondary & 15 & 38.5 & 15 & 36.6 \\
Tertiary & 17 & 43.6 & 16 & 39.0 \\
& $\mathbf{3 9}$ & $\mathbf{1 0 0 . 0}$ & $\mathbf{4 1}$ & $\mathbf{1 0 0 . 0}$ \\
\hline
\end{tabular}


Table 6 Languages spoken by children and teachers

\begin{tabular}{lllllll}
\hline S/No. & Languages spoken & & \multicolumn{2}{l}{ Children } & & \multicolumn{2}{l}{ Teachers } \\
& & Frequency & \% of N* & & Frequency & \% of N** \\
\hline 1 & English & 81 & 49.4 & 32 & 82.1 \\
2 & Hausa & 118 & 73.8 & 30 & 76.9 \\
3 & Nupe & 80 & 40.9 & & 20 & 51.3 \\
4 & Gwari & 9 & 13.4 & & 5.1 \\
5 & Arabic & 33 & 20.1 & & 23 & 59.0 \\
\hline
\end{tabular}

Sample size: Children $\left(\mathrm{N}^{*}=164\right)$; Teachers $\left(\mathrm{N}^{* *}=39\right)$

to music" and 5\% said they used it for "learning". A smaller proportion used the mobile phone for "For reading Qur' an and listening to preaching/Islamic lectures" $(2 \%)$, "for keeping record and snapping messages/pictures" $(2 \%)$ and "to access social media" (2.4\%). Unsurprisingly, of the devices presented to the children, only the mobile phone was identified as being used mobile to access social media. Of the children that responded to this open-ended question, the highest proportion of them $(8 \%)$ used the computer mostly to "watch film, play game, and listen to music". Next to this, was the use of the computer "to access information and news" (3\%) and "for word processing and typing" (3\%). Two percent (2\%) each used the computer for "learning", for the purpose of "reading Qur'an, listening to preaching and Islamic lectures", for "keeping record and snapping messages and pictures", and to send messages, receive call, browse and download information.

\subsubsection{Parent's familiarity with ICTs}

Parents were also asked to identify the various ICT devices of interest from photographs, and Table 9 presents information on the familiarity of the parents of the sampled pupils with ICT. The information also gives inferences about the parents' support for the use of ICTs for teaching and learning in the Almajiri school system.

Thirty-four out of the 41 sampled parents, representing $82.9 \%$, did not have a computer, with 7 of them $(17.1 \%)$ noting that they owned a computer. On the other hand, an enormous $97.6 \%$ (40) of the parents had mobile phones, while 34 of them $(82.9 \%)$ owned a television set. It then shows a majority of the parents of the sampled pupils had access to mostly mobile phone and television.

To this end, only 17 (41.5\%) of the parents confirmed they had used computers while 24 (58.5) said they had never used a computer. Similarly, because a majority of the parents owned phone and television, $92.7 \%$ of them used a phone while $82.9 \%$ of them had constant access to television. Only 2 (4.9\%) of the parents said they never used a phone while $7(17.1 \%)$ said they never saw a television.

Meanwhile, $39.0 \%$ of those that said they had seen a computer perceived that the device is very easy to use while another $39 \%$, including those that said they never used or owned a computer, perceived that computer is very difficult to use. A good 
Table 7 Children's familiarity with ICTs

\begin{tabular}{|c|c|c|c|c|c|c|}
\hline \multirow{2}{*}{$\begin{array}{l}\text { Aspects of familiarity } \\
\text { (a) Able to identify from photographs } \\
\text { shown }\end{array}$} & \multicolumn{2}{|l|}{ Computers } & \multicolumn{2}{|c|}{ Mobile phones } & \multicolumn{2}{|l|}{ Television } \\
\hline & Frequency & $\%$ & Frequency & $\%$ & Frequency & $\%$ \\
\hline Yes & 116 & 70.7 & 123 & 75.0 & 133 & 81.1 \\
\hline No & 34 & 20.7 & 15 & 9.1 & 15 & 9.1 \\
\hline No response & 14 & 8.5 & 26 & 15.9 & 16 & 9.8 \\
\hline Total & 164 & 100.0 & 164 & 100.0 & 164 & 100.0 \\
\hline (b) Confirms use of device & Frequency & $\%$ & Frequency & $\%$ & Frequency & $\%$ \\
\hline Yes & 27 & 16.5 & 90 & 54.9 & 127 & 77.4 \\
\hline No & 99 & 60.4 & 46 & 28.0 & 5 & 3.0 \\
\hline No response & 38 & 23.2 & 28 & 17.1 & 32 & 19.5 \\
\hline Total & 164 & 100.0 & 164 & 100.0 & 164 & 100.0 \\
\hline (c) How easy it was to use & Frequency & $\%$ & Frequency & $\%$ & Frequency & $\%$ \\
\hline Very easy & 15 & 9.1 & 79 & 48.2 & 127 & 77.4 \\
\hline Very difficult & 57 & 34.8 & 19 & 11.6 & 2 & 1.2 \\
\hline No response & 92 & 56.1 & 66 & 40.2 & 35 & 21.3 \\
\hline Total & 164 & 100.0 & 164 & 100.0 & 164 & 100.0 \\
\hline (d) How often the device is used & Frequency & $\%$ & Frequency & $\%$ & Frequency & $\%$ \\
\hline Once in a year & 8 & 4.9 & 15 & 9.1 & 6 & 3.7 \\
\hline Many times in a year & 24 & 14.6 & 26 & 15.9 & 62 & 37.8 \\
\hline Every week & 27 & 16.5 & 55 & 33.5 & 60 & 36.6 \\
\hline No response & 105 & 64.0 & 68 & 41.5 & 36 & 22.0 \\
\hline Total & 164 & 100.0 & 164 & 100.0 & 164 & 100.0 \\
\hline $\begin{array}{l}\text { (e) Child will be happy to use the device } \\
\text { as part of their lessons }\end{array}$ & Frequency & $\%$ & Frequency & $\%$ & Frequency & $\%$ \\
\hline Yes & 77 & 47.0 & 73 & 44.5 & 91 & 55.5 \\
\hline No & 4 & 2.4 & 82 & 50.0 & 11 & 6.7 \\
\hline No response & 83 & 50.6 & 9 & 5.5 & 62 & 37.8 \\
\hline Total & 164 & 100.0 & 164 & 100.0 & 164 & 100.0 \\
\hline
\end{tabular}

majority of the parents owned and used mobile phone and television, and the two devices were perceived by a good number of the parents as being very easy to use. For instance, $68.3 \%$ of them perceived mobile phones as very easy to use while $82.9 \%$ of them perceived television as very easy to operate. For those that said they used mobile phone and television, it was a matter of daily use. Parents that used their mobile phones everyday were $63 \%$ while $56.1 \%$ of them watched television every day.

A good percent of the parents gave support for the use of mobile phones, television, and computers, for teaching and learning in the Almajiri schools. Twentyseven per cent $(27 \%)$ of the parents gave support for the use of a computer, $51.2 \%$ gave support for the use of mobile phones and $56.1 \%$ gave support for the use of television.

Among the questions asked of parents under the section on familiarity with ICTs, parents were asked: "How do you feel about children using computers?"; "How do 
Table 8 Use of computer, mobile phones, and television by children in the sample

\begin{tabular}{llll}
\hline Categories of Use & Computer & Mobile Phone & Television \\
\hline To access information and news & $5(3.0 \%)$ & - & $17(10.4 \%)$ \\
To watch film, play game, and listen to music & $13(7.9 \%)$ & $9(5.5 \%)$ & $32(19.5 \%)$ \\
For Learning & $4(2.4 \%)$ & $8(4.9 \%)$ & $7(4.3 \%)$ \\
For Word processing (typing) & $5(3.0 \%)$ & - & - \\
For reading Qur'an and listening to preaching/Islamic lectures & $2(1.2 \%)$ & $3(1.8 \%)$ & $17(10.4 \%)$ \\
For keeping record and snapping messages/pictures & $2(1.2 \%)$ & $3(1.8 \%)$ & - \\
For sending messages, receiving call, browsing, and down- & $2(1.2 \%)$ & $22(13.4 \%)$ & - \\
$\quad$ loading information & & & - \\
To access social media & - & $4(2.4 \%)$ & - \\
\hline
\end{tabular}

$\mathrm{N}=164$

you feel about children using mobile phones?"; "How do you feel about children watching television?" The responses to the open-ended questions are presented in Table 10. Among the main reasons why the parents gave support for the integration or use of computers for teaching and learning in the Almajiri school system included the fact that the children would become familiar with the demands of a new digital world. Of those that responded to the open-ended questions, $42 \%$ of the parents indicated that they felt very good and happy about the use of computer because it makes things easy. Similarly, they were very excited about the use of television (22\%) because it enhances the learning by children while $15 \%$ mentioned the usage of computer for the enhancement of learning. Seventeen per cent of them $(17 \%)$ indicated that they were not comfortable with with the usage of mobile phones by children in school, even for learning purpose. It should be noted that $5 \%$ of the parents singled out mobile phone as being dangerous for children's use. Nevertheless, parents mentioned the distraction television can cause ( $2 \%$ of them).

\subsubsection{Teacher familiarity and use of ICTs}

With the use of a Likert response scale, teachers were asked to provide information on their frequency of use of various ICT and support devices including computers, mobile phones, and television. Their responses are presented in Table 11.

Among the various ICTs and other related devices, the mobile phone was being used more often than others by the sampled teachers. Twenty-three teachers, representing 59.0\%, used a mobile phone very often. Radio and television were the next most commonly used devices among the teachers with about $30.8 \%$ and $43.6 \%$ claiming to use radio and television, very often, respectively.

A majority of sampled teachers held the opinion that the mobile phone is the most-easy-to-use among the identified ICT devices. This might be because $89.7 \%$ of them had a mobile phone. As shown in Table 12, the mobile phone was identified as very easy to use by 32 teachers, representing $82.1 \%$. None of the sampled teachers considered mobile phones as difficult to use even though not all of them had a mobile phone. Television was seen as also very easy to use by 23 teachers, 
Table 9 Parent's familiarity with ICTs

\begin{tabular}{|c|c|c|c|c|c|c|}
\hline \multirow{2}{*}{$\begin{array}{l}\text { Aspects of familiarity } \\
\text { (a) Able to identify from photographs } \\
\text { shown }\end{array}$} & \multicolumn{2}{|l|}{ Computers } & \multicolumn{2}{|c|}{ Mobile phones } & \multicolumn{2}{|l|}{ Television } \\
\hline & Frequency & $\%$ & Frequency & $\%$ & Frequency & $\%$ \\
\hline Yes & 31 & 75.6 & 41 & 100.0 & 39 & 95.1 \\
\hline No & 10 & 24.4 & - & - & 2 & 4.9 \\
\hline Total & 41 & 100.0 & 41 & 100.0 & 41 & 100.0 \\
\hline (b) Has own device & Frequency & $\%$ & Frequency & $\%$ & Frequency & $\%$ \\
\hline Yes & 7 & 17.1 & 40 & 97.6 & 34 & 82.9 \\
\hline No & 34 & 82.9 & 1 & 2.4 & 7 & 17.1 \\
\hline Total & 41 & 100.0 & 41 & 100.0 & 41 & 100.0 \\
\hline (c) Confirms the use of the device & Frequency & $\%$ & Frequency & $\%$ & Frequency & $\%$ \\
\hline Yes & 17 & 41.5 & 38 & 92.7 & 34 & 82.9 \\
\hline No & 24 & 58.5 & 2 & 4.9 & 7 & 17.1 \\
\hline No response & - & - & 1 & 2.4 & - & - \\
\hline Total & 41 & 100.0 & 41 & 100.0 & 41 & 100.0 \\
\hline (d) How easy it was to use & Frequency & $\%$ & Frequency & $\%$ & Frequency & $\%$ \\
\hline Very easy & 16 & 39.0 & 28 & 68.3 & 34 & 82.9 \\
\hline Very difficult & 16 & 39.0 & 13 & 31.7 & - & - \\
\hline No response & 9 & 22.0 & & & 7 & 17.1 \\
\hline Total & 41 & 100.0 & 41 & 100.0 & 41 & 100.0 \\
\hline (e) How often the device is used & Frequency & $\%$ & Frequency & $\%$ & Frequency & $\%$ \\
\hline Once in a year & 4 & 9.8 & & & 2 & 4.9 \\
\hline Many times in a year & 6 & 14.6 & 6 & 14.6 & 5 & 12.2 \\
\hline At least once a week & 3 & 7.3 & 6 & 14.6 & 2 & 4.9 \\
\hline Everyday & 13 & 31.7 & 26 & 63.4 & 23 & 56.1 \\
\hline No response & 15 & 36.6 & 3 & 7.3 & 9 & 22.0 \\
\hline Total & 41 & 100.0 & 41 & 100.0 & 41 & 100.0 \\
\hline $\begin{array}{l}\text { (f) Parent support for use of the device in } \\
\text { Almajiri schools }\end{array}$ & Frequency & $\%$ & Frequency & $\%$ & Frequency & $\%$ \\
\hline Yes & 27 & 65.9 & 21 & 51.2 & 23 & 56.1 \\
\hline No & - & - & 4 & 9.8 & 1 & 2.4 \\
\hline Partially & 8 & 19.5 & 14 & 34.1 & 13 & 31.7 \\
\hline No response & 6 & 14.6 & 2 & 4.9 & 4 & 9.8 \\
\hline Total & 41 & 100.0 & 41 & 100.0 & 41 & 100.0 \\
\hline
\end{tabular}

representing 59.0\%, while 27 of them $(69.2 \%)$ held the opinion that radio was very easy to use. A laptop or computer was identified by the least number of teachers $(20.5 \%)$ as being very easy to use, perhaps because only $10(25.7 \%)$ of them owned either a laptop or desktop computer.

Concerning the use of the identified ICT devices for teaching and learning, the pervasive perception among sampled teachers was that the use of ICTs helped them to teach better. As shown in Table 13, twenty-two out of the 39 sampled teachers, representing $56.4 \%$, held the opinion that the use of ICT helped them to teach better. 
Table 10 Attitude of parents towards the use of computer, mobile phones, and television by their children

\begin{tabular}{llll}
\hline Attitude & Computer & Mobile Phones & Television \\
\hline Feeling very good and happy about it because it is easy & $17(41.5 \%)$ & $6(14.6 \%)$ & $13(31.7 \%)$ \\
Very excited about it because it enhances their learning & $6(14.6 \%)$ & $5(12.2 \%)$ & $9(22.0 \%)$ \\
Not feeling good and happy about it & - & $7(17.1 \%)$ & $1(2.4 \%)$ \\
It distracts the children & - & - & $1(2.4 \%)$ \\
It is dangerous for children & - & $2(4.9 \%)$ & - \\
Children don't need it & - & $1(2.4 \%)$ & - \\
\hline
\end{tabular}

$\mathrm{N}=41$

Not less than $41 \%$ of the teachers supported this perception with the notion that the use of ICT helped them to explain some concepts better to their pupils.

More specifically, $56.4 \%$ of the teachers strongly agreed that a computer is a good medium for teaching and learning. To this end, more than $70 \%$ of them agreed (strongly and ordinarily) that children should be allowed to have access to computers and the internet. Similarly, more than $80 \%$ agreed (strongly and ordinarily) that television, as a medium that can enable children to learn by watching, should be placed in the classroom for learning purposes, even though a very least percentage (less than $40 \%$ ) agreed that primary school children should be allowed to own a mobile phone.

The teachers were asked if their school could provide ICT devices for teaching. Surprisingly, however, only 11 of the sampled teachers $(28.2 \%)$ supported the idea that schools can provide ICT devices for teaching while 17 (43.6) of the teachers

Table 11 Teachers' frequency of use of ICTs and support devices

\begin{tabular}{|c|c|c|c|c|c|c|c|c|c|c|c|c|c|}
\hline \multirow[t]{2}{*}{$\mathrm{S} / \mathrm{N}$} & \multirow[t]{2}{*}{ ICTs \& related devices } & \multicolumn{2}{|c|}{$\begin{array}{l}\text { Very } \\
\text { often }\end{array}$} & \multicolumn{2}{|c|}{$\begin{array}{l}\text { Some- } \\
\text { times }\end{array}$} & \multicolumn{2}{|c|}{ Rarely } & \multicolumn{2}{|c|}{ Never } & \multicolumn{2}{|c|}{$\begin{array}{l}\text { No } \\
\text { Response }\end{array}$} & \multicolumn{2}{|c|}{ Total } \\
\hline & & $\mathrm{N}$ & $\%$ & $\mathrm{~N}$ & $\%$ & $\mathrm{~N}$ & $\%$ & $\mathrm{~N}$ & $\%$ & $\mathrm{~N}$ & $\%$ & $\mathrm{~N}$ & $\%$ \\
\hline 1 & Camera & 8 & 20.5 & 10 & 25.6 & 2 & 5.1 & 14 & 35.9 & 5 & 12.8 & 39 & 100.0 \\
\hline 2 & Laptop & 7 & 17.9 & 9 & 23.1 & 5 & 12.8 & 14 & 35.9 & 4 & 10.3 & 39 & 100.0 \\
\hline 3 & Mobile phone & 23 & 59.0 & 4 & 10.3 & 7 & 17.9 & 3 & 7.7 & 2 & 5.1 & 39 & 100.0 \\
\hline 4 & Projector & - & - & 4 & 10.3 & 7 & 17.9 & 23 & 59.0 & 5 & 12.8 & 39 & 100.0 \\
\hline 5 & Scanner & 1 & 2.6 & 6 & 15.4 & 4 & 10.3 & 23 & 59.0 & 5 & 12.8 & 39 & 100.0 \\
\hline 6 & Radio & 12 & 30.8 & 12 & 30.8 & 4 & 10.3 & 6 & 15.4 & 5 & 12.8 & 39 & 100.0 \\
\hline 7 & Television & 17 & 43.6 & 4 & 10.3 & 9 & 23.1 & 3 & 7.7 & 6 & 15.4 & 39 & 100.0 \\
\hline 8 & Cable TV (DSTV/GoTV/etc.) & 10 & 25.6 & 5 & 12.8 & 8 & 20.5 & 10 & 25.6 & 6 & 15.4 & 39 & 100.0 \\
\hline 9 & Video recorder & 8 & 20.5 & 10 & 25.6 & 6 & 15.4 & 9 & 23.1 & 6 & 15.4 & 39 & 100.0 \\
\hline 10 & Internet & 9 & 23.1 & 13 & 33.3 & 4 & 10.3 & 9 & 23.1 & 4 & 10.3 & 39 & 100.0 \\
\hline 11 & Printer & 2 & 5.1 & 13 & 33.3 & 5 & 12.8 & 15 & 38.5 & 4 & 10.3 & 39 & 100.0 \\
\hline 12 & Inverter & 1 & 2.6 & 4 & 10.3 & 5 & 12.8 & 21 & 53.8 & 8 & 20.5 & 39 & 100.0 \\
\hline 13 & Generator set & 9 & 23.1 & 8 & 20.5 & 4 & 10.3 & 9 & 23.1 & 9 & 23.1 & 39 & 100.0 \\
\hline 14 & Solar power & 4 & 10.3 & 5 & 12.8 & 1 & 2.6 & 17 & 43.6 & 12 & 30.8 & 39 & 100.0 \\
\hline
\end{tabular}


Table 12 Teachers' opinion on ease of use of ICTs and support devices

\begin{tabular}{|c|c|c|c|c|c|c|c|c|c|c|c|c|c|}
\hline \multirow[t]{2}{*}{$\mathrm{S} / \mathrm{N}$} & \multirow[t]{2}{*}{ ICTs \& related devices } & \multicolumn{2}{|c|}{ Very easy } & \multicolumn{2}{|c|}{ Easy } & \multicolumn{2}{|c|}{ Difficult } & \multicolumn{2}{|c|}{$\begin{array}{l}\text { Very } \\
\text { difficult }\end{array}$} & \multicolumn{2}{|c|}{$\begin{array}{l}\text { No } \\
\text { Response }\end{array}$} & \multicolumn{2}{|c|}{ TOTAL } \\
\hline & & $\mathrm{N}$ & $\%$ & $\mathrm{~N}$ & $\%$ & $\mathrm{~N}$ & $\%$ & $\mathrm{~N}$ & $\%$ & $\mathrm{~N}$ & $\%$ & $\mathrm{~N}$ & $\%$ \\
\hline 1 & Camera & 21 & 53.8 & 11 & 28.2 & 2 & 5.1 & 1 & 2.6 & 4 & 10.3 & 39 & 100.0 \\
\hline 2 & Laptop & 8 & 20.5 & 11 & 28.2 & 13 & 33.3 & 2 & 5.1 & 5 & 12.8 & 39 & 100.0 \\
\hline 3 & Mobile phone & 32 & 82.1 & 3 & 7.7 & - & - & 1 & 2.6 & 3 & 7.7 & 39 & 100.0 \\
\hline 4 & Projector & 6 & 15.4 & 10 & 25.6 & 11 & 28.2 & 8 & 20.5 & 4 & 10.3 & 39 & 100.0 \\
\hline 5 & Scanner & 4 & 10.3 & 13 & 33.3 & 10 & 25.6 & 7 & 17.9 & 5 & 12.8 & 39 & 100.0 \\
\hline 6 & Radio & 27 & 69.2 & 8 & 20.5 & 1 & 2.6 & - & - & 3 & 7.7 & 39 & 100.0 \\
\hline 7 & Television & 23 & 59.0 & 7 & 17.9 & 3 & 7.7 & 1 & 2.6 & 5 & 12.8 & 39 & 100.0 \\
\hline 8 & Cable TV (DSTV/GoTV/etc.) & 11 & 28.2 & 13 & 33.3 & 5 & 12.8 & 4 & 10.3 & 6 & 15.4 & 39 & 100.0 \\
\hline 9 & Video recorder & 15 & 38.5 & 13 & 33.3 & 2 & 5.1 & 3 & 7.7 & 6 & 15.4 & 39 & 100.0 \\
\hline 10 & Internet & 10 & 25.6 & 12 & 30.8 & 9 & 23.1 & 3 & 7.7 & 5 & 12.8 & 39 & 100.0 \\
\hline 11 & Printer & 8 & 20.5 & 15 & 38.5 & 6 & 15.4 & 4 & 10.3 & 6 & 15.4 & 39 & 100.0 \\
\hline 12 & Inverter & 3 & 7.7 & 12 & 30.8 & 11 & 28.2 & 7 & 17.9 & 6 & 15.4 & 39 & 100.0 \\
\hline 13 & Generator set & 15 & 38.5 & 12 & 30.8 & 4 & 10.3 & 2 & 5.1 & 6 & 15.4 & 39 & 100.0 \\
\hline 14 & Solar power & 7 & 17.9 & 7 & 17.9 & 10 & 25.6 & 5 & 12.8 & 10 & 25.6 & 39 & 100.0 \\
\hline
\end{tabular}

rejected the idea (see Table 14). Eleven of the teachers, representing 28.2\%, did not give any response as to whether they supported or rejected the idea.

The primary reason given by the majority that did not support the idea that schools can provide ICT devices for teaching was that Almajiri schools are not adequately funded by the government although school fees are not being charged (students only pay a very little examination fee). Another reason they gave was that students in Almajiri schools lack the sophistication to operate and maintain the devices.

\subsection{Availability of ICTs in the sampled schools}

Sixteen Almajiri schools in the study area were visited to do an observational checklist of the available ICT devices in the school as well as obtaining key information from key informants on the use of ICT devices for teaching and learning in the schools. Out of the 16 schools visited, only four had any form of identifiable ICT devices. One school (Bida-2) had a mobile phone, one spoilt television, one video recorder, some access to the internet via mobile data, and one computer printer. Zungeru-1 had one mobile phone and one printer. Bida-3 had one laptop and one printer. Bida-4 had a radio.

\subsection{Influence of child's gender on perceived ease of use of ICTs}

The following null hypothesis was proposed to test for the influence of gender on perceived ease of use of the identified ICTs:

$\mathrm{H}_{01 \text { : }}$ There is no significant association between gender of pupils in Almajiri schools and their opinion about the ease of use of the identified ICT devices. 


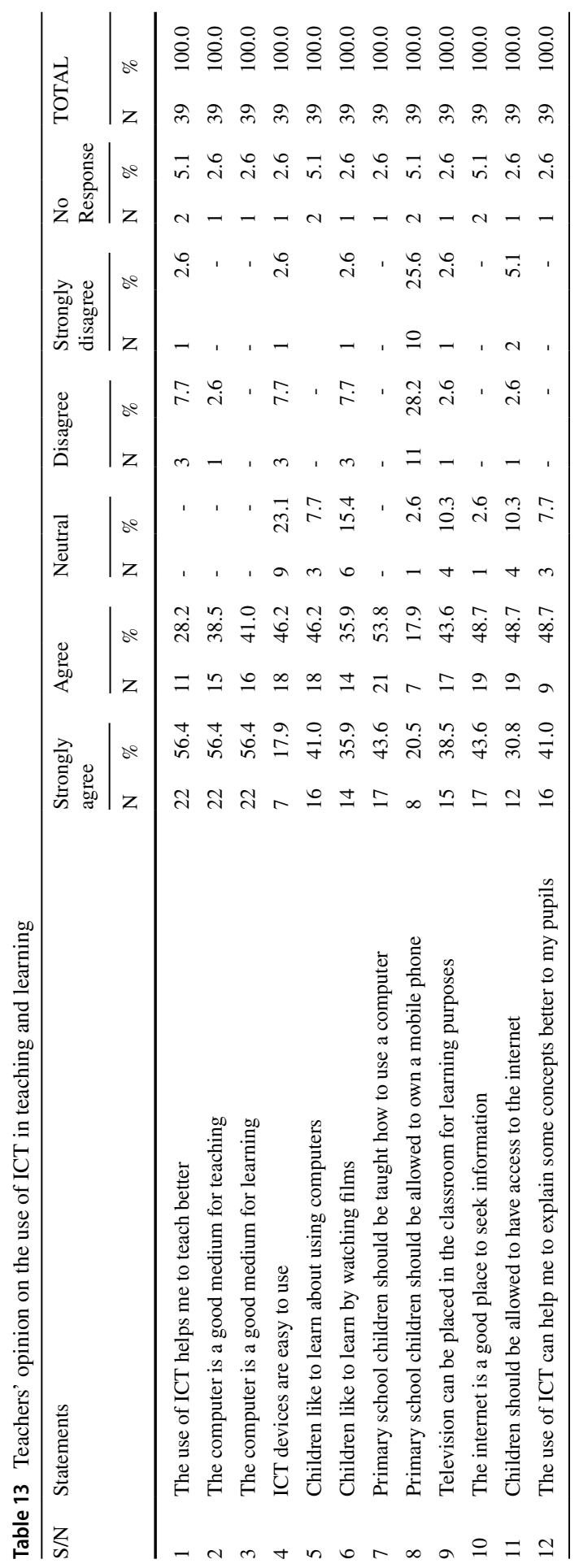


Table 14 Teachers' responses as to whether or not their school can provide ICT devices

\begin{tabular}{llr}
\hline $\begin{array}{l}\text { School can provide ICT devices } \\
\text { for teaching }\end{array}$ & Frequency & $\%$ \\
\hline Yes & 11 & 28.2 \\
No & 17 & 43.6 \\
No response & 11 & 28.2 \\
Total (N) & 39 & 100.0 \\
\hline
\end{tabular}

The chi-square test was determined from the cross-tabulation of the children's gender against their opinion on the ease of use of television, computer, and mobile phone. The results are presented in Tables 15, 16, and 17, respectively. From the result shown in Table 15 which is the cross-tabulation of the children's opinion on ease of use of television versus their gender, the Chi-square $\left(\chi^{2}\right)=4.053^{\mathrm{a}}, p=0.132$. It implies that there is no statistically significant association between gender and the ease of use of television for pupils' learning.

From the result shown in Table 16 which is the cross-tabulation of the children's opinion on ease of use of computer versus their gender, the Chi-square $\left(\chi^{2}\right)=0.621^{\mathrm{a}}$, $p=0.733$. This infers that there is no statistically significant association between gender and the ease of use of computers for pupils' learning purposes.

From the result shown in Table 17 which is the cross-tabulation of the children's opinion on ease of use of computer versus their gender, the Chi-square $\left(\chi^{2}\right)=2.130^{\mathrm{a}}$, $p=0.345$. This means that there is no statistically significant association between gender and the ease of use of mobile phones for pupils' learning purposes.

Overall, it was found that there is no association between the children's gender and their opinion on ease of use of each of the recognized ICT devices.

\section{Discussion}

Data was collected from the Almajiri children and their teachers, and from parents from the surrounding communities from each of the senatorial districts of Niger state, which is in the north-central zone of Nigeria. Analyses of the data collected revealed several findings that are discussed in this section.

It was found that none of the children in the Almajiri schools in the study area began their primary education at an age lower than 6 years. Although in line with the minimum age set for children to commence primary school in Nigeria, in comparison to most Nigerian children, those in the Almajiri schools may be disadvantaged in their assimilation of ICT arising from the lack of exposure to early child care education meant to "inculcate in the child the spirit of enquiry and creativity through the exploration of nature, the environment, art, music and the use of toys, etc." (National Policy on Education, 2013, p.5).

Less than half of the teachers sampled in the Almajiri schools have tertiary education in direct contradiction of the NPE which stipulates that the Nigeria Certificate in Education (NCE) shall be the minimum qualification for teachers in primary 


$$
\text { 完 }
$$

芒

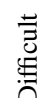

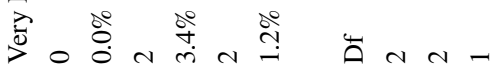

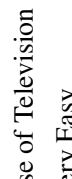

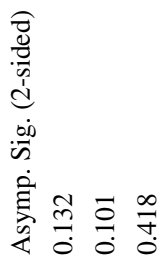

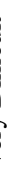
त $\mathrm{N}$ 
Table 16 Children's ease of use of computer versus gender

\begin{tabular}{|c|c|c|c|c|c|c|}
\hline \multicolumn{7}{|c|}{ Gender * Computer Cross-tabulation } \\
\hline \multirow[t]{2}{*}{$\mathrm{s}$} & & & \multicolumn{3}{|l|}{ Computer } & \multirow[t]{2}{*}{ Total } \\
\hline & & & Very Easy & Very Difficult & No Response & \\
\hline \multirow[t]{4}{*}{ Gender } & Male & Count & 11 & 36 & 58 & 105 \\
\hline & & $\%$ within Gender & $10.5 \%$ & $34.3 \%$ & $55.2 \%$ & $100.0 \%$ \\
\hline & Female & Count & 4 & 21 & 34 & 59 \\
\hline & & $\%$ within Gender & $6.8 \%$ & $35.6 \%$ & $57.6 \%$ & $100.0 \%$ \\
\hline \multirow{2}{*}{\multicolumn{2}{|c|}{ Total }} & Count & 15 & 57 & 92 & 164 \\
\hline & & $\%$ within Gender & $9.1 \%$ & $34.8 \%$ & $56.1 \%$ & $100.0 \%$ \\
\hline \multicolumn{7}{|c|}{ Chi-Square Tests } \\
\hline & & & Value & Df & \multicolumn{2}{|c|}{ Asymp. Sig. (2-sided) } \\
\hline \multicolumn{3}{|c|}{ Pearson Chi-Square } & $0.621^{\mathrm{a}}$ & 2 & 0.733 & \\
\hline \multicolumn{3}{|c|}{ Likelihood Ratio } & 0.648 & 2 & 0.723 & \\
\hline \multicolumn{3}{|c|}{ Linear-by-Linear Association } & 0.322 & 1 & 0.570 & \\
\hline \multicolumn{3}{|c|}{$\mathrm{N}$ of Valid Cases } & 164 & & & \\
\hline
\end{tabular}

a. 0 cells $(0.0 \%)$ have an expected count less than 5 . The minimum expected count is 5.40

schools. The NCE is awarded after a three-year course at the tertiary education level. Obanya (2008) stresses that the goals and objectives of any educational policy would not yield any results if teachers are left out of the equation. A situation where a sizeable number of teachers in the Almajiri system have less than the minimum teaching qualification needs to be addressed if the teachers are expected to handle subjects such as Information Technology or use ICT devices and tools for teaching. The National Teachers Institute (NTI), which was set up to upgrade under-qualified and untrained teachers in Nigeria, among other objectives, has a lot to do in this regard.

The multiplicity of languages identified among the stakeholders in the Almajiri school system supports the combination or mixture of languages for teaching in the Almajiri education system. Nevertheless, this multiplicity of languages may be detrimental for children in grades 4 -6 when compared to their counterparts in the traditional schools because from the fourth grade, "English shall progressively be used as a medium of instruction and the language of the immediate environment and French and Arabic shall be taught as subjects" (National Policy on Education, 2013, p.8).

Little or no ICT learning and teaching devices were found in the Almajiri schools in the study. The little or no availability of ICTs in Almajiri schools negates the desire for early introduction of information technology and computer studies in primary schools. Compared to traditional schools, this is a huge disadvantage for Almajiri children. For instance, in a study investigating the usage of ICT in Osun State primary schools in the south-west zone of Nigeria, $68 \%$ of the teachers sampled answered "Yes" to the question, "Do you use computer in your school as a supplement to chalking and talking?" (Abass \& Ayo, 2013). Their result is a stark contrast to the finding of this study, seven years on. 


$$
\text { 完 }
$$

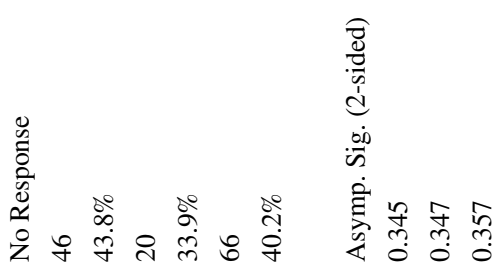

离。竞

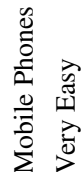

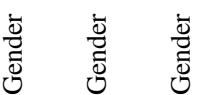

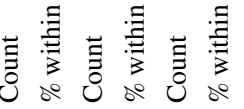

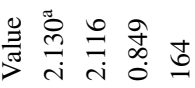


Although majority of the sampled pupils confirmed they had never used a computer for learning, it can be concluded that the Almajiri children would welcome the use of audio-visual technologies that incorporate smart television sets or projectors in the classroom because a large majority of them confirmed that they had seen and learnt through television, including watching films. Studies such as that by UlloaSalazar and Díaz Larenas (2018), confirmed that the inclusion of audio-visual aids improves the understanding and, subsequently, the performance of young learners.

A good number of students confirmed that they used and had learnt through mobile phones. Equally, among the various ICTs and other related devices, the mobile phone was being used more often than others by teachers in the Almajiri schools. Mobile phone penetration in low economic regions and rural areas has been phenomenal. In Nigeria, adults who report owning a mobile phone are $80 \%$ of the population with $32 \%$ owning a smartphone and $48 \%$ a basic phone - as reported by a 2017 Pew Research Centre study (Elliott, 2019). The same study found that education had a direct relationship with mobile phone ownership with the less educated less likely to own a mobile phone and even less likely to own a smartphone. Given the importance of smartphones as a reasonable substitute for laptops or tablets, there is a need for cost-effective smartphones that can be made widely available to the Almajiri children and their teachers.

There is a broad range of what the students in the Almajiri system use the identified ICT devices for in their learning endeavours. These include using a computer to access data, to access all subjects online, read Qur' an, play games, watch a film, and for typing. They also used mobile phone to make calls, listen to music, send messages, browse and download, chat, play games, and, more importantly, snap pictures and lesson notes while they used television for watching educative programmes, films, football matches, cartoons, comedy, news, Wa'zil (Islamic preaching), and Islamic programmes on television. All these uses correspond with the nineteen distinct rationales identified in the meta-analysis study carried out by Fox and Twining (2006).

A large number of pupils perceived computers as very difficult to use in comparison to how they perceived the use of television and mobile phones, and this is as a result of the frequency at which they used the devices. A majority of teachers held the opinion that mobile phones were easier to use relative to computers. This could be because only a small number of them owned either a laptop or desktop computer. These findings seem to support Valk et al. (2010) proposition that a mobile phone is the most suitable, of all ICTs, for advancing education.

The pervasive perception among sampled teachers was that the use of ICTs helped them to teach better. This is similar to the finding by Tella et al. (2007, p.222) that most teachers perceived ICT as very useful and made teaching and learning easier which led to their recommendation that "professional development policies should support ICT-related teaching models" and that "emphasis should be placed on the pedagogy underlying the use of ICTs for teaching and learning".

A majority of parents in the Almajiri school communities gave support for the use of computer and television, in particular, and mobile phone in some cases, for teaching and learning in the Almajiri schools. The fact that most of these Almajiri pupils and their parents are familiar with information technology tools necessitates 
the need for timely integration of ICT in Almajiri schools. According to an earlier study by Ghavifekr and Rosdy (2015), the fact that students are familiar with ICT tools and aware of the tremendous benefits of the tools for enhancing their learning, makes it vital for school administrators to provide a technology-friendly environment for teaching and learning. Among the main reasons why parents gave support for the integration or use of computers for teaching and learning in the Almajiri school system is that children would be made to flow with the demands of the new digital world, even though such an advantage would come with its challenges. Integration of ICT into teaching and learning would allow pupils to have universal access to information, think beyond their immediate environ, and have first-hand experience with the use of tools which are inaccessible in their various rural inhabitants (Kalaš et al., 2012).

While less than $40 \%$ of the teachers sampled agreed that primary school children should be allowed to own a mobile phone, a majority of the teachers agreed that television, as a medium that can enable children to learn by watching, should be placed in the classroom for learning purposes. This is in contrast to the recommendation by Aderinoye et al. (2007) that the transformation of nomadic education in Nigeria requires the introduction of ICT tools such as less sophisticated mobile phones to the pupils to enhance their ICT literacy and learning. This gives further indications that ICT devices have been shown to enhance the quality of education in several ways (e.g. Andersen \& Sorensen, 2017; Kardijan \& Yundayani, 2019; Suana, 2018).

A majority of pupils noted that they would be happy to use each of the identified ICT devices; thereby there is a higher chance of increasing learner motivation and engagement. Moreover, ICT devices among the pupils will facilitate the acquisition of basic skills. Furthermore, ICT devices are regarded as transformational tools which, when used appropriately, can promote the shift to a learner-centred environment, thereby improving engagement and knowledge retention as indicated by Zaranis et al. (2013), and also promotes socio-economic development (Ayo and Mbarika, 2017). These two studies assert that when ICT devices are integrated into lessons, pupils have a higher tendency to become more engaged in their lessons because technology provides different opportunities to make it more fun and enjoyable in terms of teaching the same thing in different ways.

Among teachers and pupils, no significant relationship between their gender and their opinion about the ease of use or ability to use any of the identified ICT devices was found. In other words, demographic variables are not important factors that determine the use of ICT for teaching and learning by both the teachers and learners. This study, therefore, does not deviate from the recurring findings (Mwendwa, 2017; Renukadevi et al., 2018) on the factors that determine the use of ICT for teaching and learning. The factors, rather than any demographic variables, include anxiety from dealing with equipment, a sense of loss of control over the teaching situation, hardware and software availability, lack of technical support, time and efforts for training, and remaining up to date with the appropriate technology in the classroom. Also, Zamani (2014) investigated differences between boys and girls according to their access and usage of mobile devices for learning, and found that there were 
no differences between boys and girls regarding their attitudes toward using mobile devices for learning.

However, the findings of Park et al., (2019) reveal that gender variation serves as a moderating factor in the use and adoption of communication technologies which contradicts ours. In their TAM-based work, gender was used as a moderating factor between perceived usefulness and intention of use and concluded that the effect which perceived usefulness has on the intention to use is higher for males.

Components of the TAM model were operationalised in different ways in order to achieve the goals of the research. For the questionnaire developed to collect data from the children, the attitude and experience components of the model were the focus and a distinction was made between those that have used a device and those that have not in order to identify what the children used the device for in actual system use. The behavioural aspect was limited to having the child identify the device in question from photographs. This was also the case for the questionnaire used to collect data from the parents except that the social influence of the parent's Islamic faith was recognized; hence for each device, the parent was asked how they felt about children using it and if they would support the use of such a device in Almajiri schools.

The questionnaire developed to collect data from the teachers was more detailed than that of children and parents. For example, the questionnaire included a question on how the teacher felt about children using the computer to learn and how the teacher felt about using the computer to teach their class. Furthermore, the potential use of ICT in the classroom was sought through a section of twelve statements on the use of ICT in teaching and learning rated on a 5-point Likert scale of "strongly agree" to "strongly disagree".

The ICT challenges faced by Almajiri schools in terms of lack of genuine software, inadequate computer in the classroom, low-speed internet, lack of proper training skills, unavailability of latest ICT equipment, lack of expert technical support, and poor administrative support did not allow the schools' officials to see the changes required in education in the twenty-first century. ICT devices in Almajiri schools will not only transform learning but also the teaching processes. An ICT enabled educational transformation suggested by the current study will increase learning gains for pupils to develop creativity, communication skills, and other thinking skills. This is because ICT enables education to support, enhance, and optimise the delivery of information.

One major factor that hinders the effective use of ICT in schools is the lack of funding (Eze et al., 2013), and this was also identified as a challenge by the teachers in the Almajiri schools. Assessing the challenges or difficulties envisaged in the use of ICT has been addressed by several researchers (Al-Faki \& Khamis, 2014; Mikre, 2011; Rubagiza et al., 2011; Salehi \& Salehi, 2012).

The intention of the study is to identify the prospects and challenges of using ICT in the education of Almajiri children. The findings from the schools visited reveal a near absence of ICT infrastructure. As at the time of the data collection, no school in 
the sample used any ICT device in the classroom. In the recommendations section, we have identified television as an acceptable means of initiating cooperative learning processes in the classroom.

Thus, through this study, we advocate that learning should be supported by the availability and use of ICT devices not only in the Almajiri schools, but across all schools including the traditional ones. To this end, just like the New Zealand Government had done, there is a need to incorporate digital citizenship into the Nigeria learning environment. With the lessons from the ravage of Coronavirus (COVID-19), learning should no longer be restricted to the physical space. Seamless learning that allows learning anytime, anywhere (Wong \& Looi, 2011) should be incorporated and encouraged at all levels of education, not only in Almajiri schools. This is possible and will be effective if the Nigeria Government is committed to enhancing digital citizenship among its populace. Commitment to digital citizenship will result not only in increased availability of IT equipment, it will also ensure increased internet accessibility and penetration among citizens. With these positive results, students and teachers will have easy access to IT equipment for frequent use not only in schools but also at home. When students and teachers have frequent and easy access to IT equipment, their digital literacy skills, which should be an essential life skill of digital citizens (Bunker, 2010), will gradually increase; thereby improving the quality of learning among students.

As it is already confirmed by this study, smart mobile phone is one of the most effective ICT equipment for teaching and learning. Although perception among a majority of teachers is that pupils should not be allowed to have frequent access to phone, the idea of digital citizenship being advocated for Nigeria learning environment will be unfulfilled without mobile phone. So, mobile phones as well as interactive whiteboard and television should be the main crucial IT devices for teaching and learning. These devices will enable interactive and collaborative learning among students as they will also enhance the possibilities for teachers to visualize abstract concepts they teach students. Since mobile phone in particular can increase capacity for off-site learning, it will also enhance individual learning at home; thereby there will be a seamless migration from school to home while collaborative, co-operative and interactive learning process among students can be guaranteed by adequate teachers' participation and monitoring.

To further enhance quality of learning while incorporating off-site seamless learning, Nigeria Government should also make use of television to improve educational broadcasting. As this study has also established, television is an effective device for learning. Part of the idea of digital citizenship being advocated should be the exploration of the benefit of educational broadcasting through television. Educational programmes should be broadcast at certain peak periods when children will be at home to augment what they have learnt in school during school hours. Nigeria needs to maximize the great learning opportunities being afforded by television through educational broadcasting to improve leaning quality and individual learning at home. 


\section{Recommended strategies for success in the use of ICTs for Almajiri education}

The findings from the study have various implications for ICT enabled education of Almajiri children in Nigeria. These are outlined below along with some recommendations:

- The dominance of the English language for computer systems and applications is a potential barrier to ICT adoption for educating the Almajiri given the finding that although the English language is the official language for teaching in Nigerian schools, a majority of the children and their teachers used other languages such as Hausa more frequently. To encourage the adoption of ICT, computer systems, applications, and courseware written in the most commonly spoken languages are needed.

- The Almajiri schools hardly get the teaching and learning facilities they require, therefore, there is a need to make adequate provision in this regard to enhance modes of communication, cost-efficiency in the long run, better teaching and learning methods, and easy student management. Facilities for ICT infusion, such as computers, projectors, smart televisions, and power backup, should be provided.

- A sizeable number of the pupils confirmed that they used and had learnt through mobile phone and other related devices; this avenue can be further explored to improve engagement, improve knowledge retention, encourage individual learning, encourage collaboration and enhance lesson delivery and class management for teachers.

- The Nigerian government needs to leverage the power of ICT devices for Almajiri schools especially because of the enthusiasm showed by the pupils and their teachers. Moreover, the benefits of ICT in teaching and learning far outweigh the disadvantages. The adoption of ICT is required to develop new, innovative ways to interact and communicate with students, higher engagement rates, faster learning, and improved teaching methods all of which invariably benefit the country at the end of the day.

- The Nigerian government should make the Nigeria Certificate in Education (NCE) a minimum qualification of teachers in Almajiri education. This will help bridge the divide between the Almajiri education and the conventional schools in Nigeria. It is important because many of the teachers in Almajiri schools are not trained in the modern techniques used by conventional school teachers, and hence may be seen as not in tune with modern trends. This reflects back upon the subject matter of their lessons and the interest of pupils for a laudable future. The adoption of modern teaching facilities and techniques will go a long way in increasing the percentage of progress over time and encourage pupils to go into various fields of learning. 


\section{Conclusion}

The government of Nigeria has rolled out various policies towards reducing the exclusion of Almajiris in areas of education, economic empowerment, child abuse, and crime, with not much impact. Based on the results achieved by others on the use of ICT to improve learning and aid teaching, this study sought to examine a range of issues that could promote or limit the adoption of ICT in the education of the Almajiri in Nigeria. It is expected that the recommendations from this paper would serve as a guide for policymakers, funding agencies, researchers, educationists, NGOs, courseware developers, and philanthropists, in the quest to improve the educational achievement of the Almajiri children and eliminate the divide they experience in society.

Acknowledgements This work was supported by Tertiary Education Trust Fund (TetFund), Ministry of Education, Federal Government of Nigeria 2016-2017 Institutional Based Research Grant.

\section{Declarations}

All authors listed have significantly contributed to the development and the writing of this article.

\section{References}

Abass, B. T., \& Ayo, O. (2013). The usage of information and communication technology in Nigeria primary schools: Problems and prospects. World Journal on Educational Technology, 5, 201206. https://arastirmax.com/en/system/files/dergiler/159831/makaleler/5/1/arastrmx_159831_5_pp_ 201-206.pdf. Accessed 29 Oct 2020.

Addo, H. (2001). Utilizing information and communication technology for education and development: Issues and challenges for developing countries. IFLA Journal, 27(3), 143-151.

Adedigba, A. (2019). Eight million out-of-school children in 10 Nigerian states and Abuja-UNICEF. https://www.premiumtimesng.com/news/headlines/335352-eight-million-out-of-school-childrenin-10-nigerian-states-and-abuja-unicef.html\#: :text=The\%20United $\% 20$ Nations $\% 20$ Children's $\%$ 20Fund,out\%2Dof\%2Dschool\%20children.\&text=Mr\%20Kawkins\%20also\%20said\%20over,crisis\% 20in\%20the\%20North\%2Deast. Retrieved on June 24, 2019.

Aderinoye, R. A., Ojokheta, K. O., \& Olojede, A. A. (2007). Integrating mobile learning into nomadic education programme in Nigeria: Issues and perspectives. The International Review of Research in Open and Distributed Learning, 8(2).

Adu, E. O., \& Olatundun, S. A. (2013). The use and management of ICT in schools: Strategies for school leaders. European Journal of Computer Science and Information Technology, 1(2), 10-16.

Aghedo, I., \& Eke, S. J. (2013). From alms to arms: The Almajiri phenomenon and internal security in Northern Nigeria. The Korean Journal of Policy Studies, 28(3), 97-123.

Agile, H. E. (2018). Expanding access to education opportunity in Nigeria: Matters arising. International Journal of Scientific Research in Education, 11(3), 345-356. http://www.ijsre.com. Accessed 20 June 2020.

Ajayi, J. A., \& Oloruntimehin, B. O. (1976). West Africa in the anti-slave trade era. The Cambridge History of Africa, 6, 200-221.

Ajzen, I., \& Fishbein, M. (1980). Understanding attitudes and predicting social behaviors. Prentice-Hall. Albugami, S., \& Ahmed, V. (2015). Success factors for ICT implementation in Saudi secondary schools: From the perspective of ICT directors, head teachers, teachers and students. International Journal of Education and Development Using Information and Communication Technology, 11(1), 36-54.

Al-Faki, I. M., \& Khamis, A. H. (2014). Difficulties facing teachers in using interactive whiteboards in their classes. American International Journal of Social Science, 3(2), 136-158. 
Al-Huneini, H., Walker, S. A., \& Badger, R. (2020). Introducing tablet computers to a rural primary school: An activity theory case study. Computers \& Education, 143.

Ali, I., \& Proctor, J. (2005). Information and communication technology (ICT) education in the city school, Pakistan: A success story in the large-scale introduction of the UK national curriculum's ICT component in Pakistan. Aslib Proceedings, 57(2), 123-130. https://doi.org/10.1108/00012 530510589092.

Ammenwerth, E. (2019). Technology acceptance models in health informatics: TAM and UTAUT. Studies in Health Technology and Informatics, 263, 64-71.

Andersen, H. V., \& Sorensen, E. K. (2017). Enhancing understanding, flow and self-efficacy in learners with developmental and attention difficulties through ICT-based interventions. European Journal of Open, Distance and E-learning, 20(1), 154-175.

Ayo, C. K., \& Mbarika, V. (Eds.). (2017). Sustainable ICT adoption and integration for socio-economic development. IGI Global. https://doi.org/10.4018/978-1-5225-2565-3.

Bunker, B. (2010). A summary of international reports, research and case studies of digital literacy: Including implications for New Zealand of adopting a globally-recognised digital literacy standard. http://www.iitp.org.nz/files/201001\%20Digital\%20Literacy\%20Research\%20Report.pdf. Accessed 29 Oct 2020.

Carmona, M. G., \& Marin, J. A. M. (2013). ICT trends in education. European Scientific Journal, 9(19).

Carr, C. T., \& Hayes, R. A. (2015). Social media: Defining, developing, and divining. Atlantic Journal of Communication, 23(1), 46-65.

Cartelli, A. (Ed.). (2013). Fostering 21st century digital literacy and technical competency. IGI Global.

Ciccarelli, M., Chen, J. D., Vaz, S., Cordier, R., \& Falkmer, T. (2015). Managing children's postural risk when using mobile technology at home: Challenges and strategies. Applied Ergonomics, 51, 189-198. https://doi.org/10.1016/j.apergo.2015.04.003.

Clarke, P. B. (1978). Islam, education and the developmental process in Nigeria. Comparative Education, 14(2), 133-141.

Cox, M. J., \& Marshall, G. (2007). Effects of ICT: Do we know what we should know? Education and Information Technologies, 12(2), 59-70. https://doi.org/10.1007/s10639-007-9032-X.

David, S. (2019). Nigeria: 13m out-of-school children in Nigeria, a time bomb. Daily Trust.

Davis, Bagozzi, \& Warshaw. (1989). Perceived usefulness, perceived ease of use, and user acceptance of information technology. MIS Quarterly, 13, 319-340.

Drigas, A., Kokkalia, G., \& Lytras, M. D. (2015). ICT and collaborative co-learning in preschool children who face memory difficulties. Computers in Human Behavior, 51, 645-651. https://doi.org/10. 1016/j.chb.2015.01.019.

Elliott, R. (2019). Mobile phone penetration throughout sub-Saharan Africa. https://www.geopoll.com/ blog/mobile-phone-penetration-africa/. Accessed on October 29, 2020.

Eze, S. C., Awa, H. O., Okoye, J. C., Emecheta, B. C., \& Anazodo, R. O. (2013). Determinant factors of information communication technology (ICT) adoption by government-owned universities in Nigeria: A qualitative approach. Journal of Enterprise Information Management, 26(4), 427-443. https://doi.org/10.1108/JEIM-05-2013-0024.

Fafunwa, A. B. (1974). Education in the mother tongue: A Nigerian experiment. Journal of African studies, 1(3), 285.

Federal Ministry of Education (1986). Blueprint on Nomadic education (fair deal for the Nomads).https:// books.google.com.ng/books?id=c6aFtgAACAAJ. Accessed on October 20, 2020.

Federal Republic of Nigeria (2004). National policy on education (4th edition). NERDC. https:// www.goodbooksafrica.com/2011/08/national-policy-on-education-4th_31.html. Accessed on October 23, 2020.

Fernández-Gutiérrez, M., Gimenez, G., \& Calero, J. (2020). Is the use of ICT in education leading to higher student outcomes? Analysis from the Spanish autonomous communities. Computers \& Education, 157, 103969. https://doi.org/10.1016/j.compedu.2020.103969.

Fishbein, M., \& Ajzen, I. (1975). Belief, attitude, intention, and behavior: An introduction to theory and research. Reading, MA: Addison-Wesley.

Fox, B., \& Twining, P. (2006). Comparing perspectives on the role of ICT in education. Paper presented at the Society for Information Technology \& Teacher Education 2006 Conference (SITE), Orlando, Florida. (pp. 1551-1558). Association for the Advancement of Computing in Education (AACE). 
Ghavifekr, S., \& Rosdy, W. A. W. (2015). Teaching and learning with technology: Effectiveness of ICT integration in schools. International Journal of Research in Education and Science (IJRES), 1(2), 175-191.

Guemide, B., \& Benachaiba, C. (2012). Exploiting ICT and E-Learning in Teacher's Professional Development in Algeria: The Case of English Secondary School Teachers. Turkish Online Journal of Distance Education, 13(3), 33-49.

Hong, K.-S., \& Songan, P. (2011). ICT in the changing landscape of higher education in Southeast Asia. Australasian Journal of Educational Technology, 27(8), 1190-1207.

Ibrahim, A. M., \& Sanda, H. U. (2019). ICT-media exposure and HIV/AIDS awareness among adolescent almajiri pupils in the North-East of Nigeria: A knowledge, attitude and practice conceptual review. 15-28.

Ibrahim, A. M., Sanda, H. U., \& Al-Sadique, A. S. S. (2019). Online media exposure and HIV/AIDS awareness among adolescent Almajiri pupils in North-Eastern Nigeria: Knowledge, attitude, and practice. International Journal, 5(1), 67-79.

Ifinedo, E., Rikala, J., \& Hämäläinen, T. (2020). Factors affecting Nigerian teacher educators' technology integration: Considering characteristics, knowledge constructs, ICT practices and beliefs. Computers \& Education, 146, 103760. https://doi.org/10.1016/j.compedu.2019.103760.

Jain, S., Dubey, S., \& Jain, S. (2016). Designing and validation of questionnaire. International Dental \& Medical Journal of Advanced Research, 2(1), 1-3.

Kabir, F. S., \& Kadage, A. T. (2017). ICTs and educational development: The utilization of mobile phones in distance education in Nigeria. Turkish Online Journal of Distance Education, 18(1), 63-76.

Kalaš, I., Bannayan, H. E., Conery, L., Laval, E., Laurillard, D., Lim, C. P., Musgrave, S., Semenov, A., \& Turcsányi-Szabó, M. (2012). ICT in Primary Education: Analytical survey. Volume 1: Exploring the origins, settings and initiatives. Moscú: IITE, UNESCO.

Kardijan, D., \& Yundayani, A. (2019). The challenges of pedagogy and the application of ICT in applying english for academic purposes course: Teachers' insights. International Journal of Innovation, Creativity and Change, 9(1), 197-213.

Kennedy, G. E., Judd, T. S., Churchward, A., Gray, K., \& Krause, K.-L. (2008). First year students' experiences with technology: Are they really digital natives? Australasian Journal of Educational Technology, 24(1), $108-122$.

Kerckaert, S., Vanderlinde, R., \& van Braak, J. (2015). The role of ICT in early childhood education: Scale development and research on ICT use and influencing factors. European Early Childhood Education Research Journal, 23(2), 183-199.

Lau, P. W. C., Lau, E. Y., Wong, D. P., \& Ransdell, L. (2011). A systematic review of information and communication technology-based interventions for promoting physical activity behavior change in children and adolescents. Journal of Medical Internet Research. https://doi.org/10.2196/jmir.1533.

Leung, W. M. V. (2011). Diverse learning experiences with information and communication technologies in hong kong kindergartens: Perspectives from children. International Journal of Learning, 18(2), 305-318. https://doi.org/10.18848/1447-9494/cgp/v18i02/47474.

Ling, L.W., Downe, A.G., Ahmad, W.F.W., Lai, T.T. (2011). Determinants of computer usage among educators: A comparison between the UTAUT and TAM models, National postgraduate conference, Kuala Lumpur, 1-6 https://doi.org/10.1109/NatPC.2011.6136322.

Magashi, S. B. (2015). Education and the right to development of the child in Northern Nigeria: A proposal for reforming the Almajiri institution. Africa Today, 61(3), 65-83.

Marangunić, N., \& Granić, A. (2015). Technology acceptance model: A literature review from 1986 to 2013. Universal Access in the Information Society, 14(1), 81-95.

Mdlongwa, T. (2012). Information and Communication Technology (ICT) as a means of enhancing education in schools in South Africa: Challenges benefits and recommendations. AISA Policy Brief, 80, 1-8.

Melor, M. Y., Maimun, A. L., \& Chua, P. L. (2009). Language learning via ICT: Uses, challenges and issues. WSEAS Transactions on Information Science and Applications, 6(9), 1453-1467.

Mikre, F. (2011). The roles of information communication technologies in education: Review Article with emphasis to the computer and internet. Ethiopian Journal of Education and Sciences, 6(2), 109-126.

Mingaine, L. (2013). Leadership challenges in the implementation of ICT in public secondary schools, Kenya. Journal of Education and Learning. https://doi.org/10.5539/jel.v2n1p32.

Moti, U. G. (2010). The challenges of access to university education in Nigeria. DSM Business Review, 2(2), 27-56. 
Mun, Y. Y., Jackson, J. D., Park, J. S., \& Probst, J. C. (2006). Understanding information technology acceptance by individual professionals: Toward an integrative view. Information \& Management, 43(3), 350-363.

Mwendwa, N. K. (2017). Perception of teachers and principals on ICT integration in the primary school curriculum in Kitui county, Kenya. European Journal of Education Studies, 3(7), 408-1430.

National Policy on Education (2013). National policy on education, 6th edition. Lagos: Nigerian Educational Research and Development Council (NERDC). https://educatetolead.files.wordpress.com/ 2016/02/national-education-policy-2013.pdf. Accessed on October 29, 2020.

Obanya, P. A. I. (2008). Reforming educational reforms. In A. R. Lawal, S. A. Jimoh, S. A. Olorundare, \& N. Y. S. Ijaiya (Eds.), Education reforms in Nigeria: Past, present and future (pp. 24-46). Ibadan: Stirling-Horden Publishers.

Odumosu, O., Odekunle, S. O., Bolarinwa, M. K., Taiwo, O., Ajala, A., Alonge, S. K., Aliyu, I. A., \& Akujobi, C. (2013). Manifestations of the Almajirai in Nigeria: Causes and consequences. Nigerian institute of social and economic research.

Ogeno, J. O. (1993). A philosophical examination of epistemological and moral bases of African indigenous education with particular reference to the Luo of Kenya. [Unpublished Phd dissertation]. Kenyatta University, Nairobi Kenya.

Okugbeni, R. E. (2013). Basic education and the rights of the Almajiri child. The Rhetoric of Universalism in Nigeria (Master's thesis, Institute of Social Studies (ISS), Hague, Netherlands).

Oladosu, A. G. A. (2012). Arabic and Islamic education in Nigeria: The case of Al-Majiri schools. International Journal of Educational and Pedagogical Sciences, 6(11), 3265-3269.

Olaniran, S. O. (2013). Education for including the excluded: Case study of Almajiri education in Nigeria. Proceedings of the 2013 International Pre-Conference of the AAACE, 180-189.

Olatunji, J. F., Lofty, A. N., \& D., \& Jacob, O. . (2016). ICTs and child labour in Nigeria: Patterns, implications and prevention strategies. International Journal of Science and Research, 5(5), 2051-2058.

Park, C., Kim, D. G., Cho, S., \& Han, H. J. (2019). Adoption of multimedia technology for learning and gender difference. Computers in Human Behavior, 92, 288-296.

Plowman, L., \& Stephen, C. (2003). A ‘benign addition'? Research on ICT and pre-school children. Journal of computer assited learning, 19(2), 149-164.

Rabah, J. (2015). Benefits and challenges of information and communication technologies (ICT) integration in Québec english schools. Turkish Online Journal of Educational Technology, 14(2), 24-31.

Renukadevi, S., Rajarajan, S., Vedanayagi, R., \& Raja, J. (2018). Factors Influencing the effective use of ICT in education and learning - Indian perspective. JETIR., 5(8), 327-331.

Rogers, P. L. (1999). Barriers to adopting emerging technologies in education. ERIC Document Reproduction. No. ED429556. Technology, 36, 327-329.

Rubagiza, J., Were, E., \& Sutherland, R. (2011). Introducing ICT into schools in Rwanda: Educational challenges and opportunities. International Journal of Educational Development. https://doi.org/10. 1016/j.ijedudev.2010.06.004.

Salehi, H., \& Salehi, Z. (2012). Challenges for using ICT in education: teachers' insights. International Journal of e-Education, e-Business, e-Management and e-Learning, 2(1), 40-43.

Sangra, A., \& Gonzalez-Sanmamed. (2016). The role of information and communication technologies in improving teaching and learning processes in primary and secondary schools. Research in Learning and Technology, 18(3), 207-220.

Saruji, M. A. M., Hassan, N. H., \& Drus, S. M. (2017). Impact of ICT and electronic gadget among young children in education: A conceptual model. 6th International Conference on Computing and Informatics, ICOCI 2017. https://doi.org/10.1116/1.578265.

Scurry, D., Ensminger, D., \& Haab, M. (2005). A model for integrating instructional technology into higher education. British Journal of Educational Technology, 36, 327-329.

Selwyn, N., \& Bullon, K. (2000). Primary school children's use of ICT. British Journal of Educational Technology. https://doi.org/10.1111/1467-8535.00165.

Sharma, A., Gandhar, K., Sharma, S., \& Seema, S. (2011). Role of ICT in the process of teaching and learning. Journal of Education and Practices, 2(5), 30-31. https://www.researchgate.net/publication/279640233_Role_of_ICT_in_the_Process_of_Teaching_and_Learning. Accessed 11 Jan 2020.

Shuaibu, H. A., \& Jimoh, A. O. (2011). Assessment of socioeconomic, demographic and health problems of al-majiri in Sokoto State, North-Western Nigeria. International Journal of Tropical Medicine, $6(3), 58-60$.

Streatfield, D., \& Markless, S. (2008). Evaluating the impact of information literacy in higher education: Progress and prospects. Libri, 58(2), 102-109. 
Suana, W. (2018). Students' internet access, internet self-efficacy, and internet for learning physics: Gender and grade differences. Journal of Technology and Science Education, 8(4), 281-290.

Suleiman, S. R. (1990). Subversive intent: Gender, politics, and the avant-garde. Harvard University Press.

Taiwo, F. J. (2013). Transforming the Almajiri education for the benefit of the Nigerian society, 3(9), 67.

Taylor, A. D. \& Ogbogu,C. O. (2016). The effects of school feeding programme on enrolment and performance of public elementary school pupils in Osun State, Nigeria. World Journal of Education, 6(3). https://doi.org/10.5430/wje.v6n3p39.

Tella, A., Tella, A., Toyobo, O. M., Adika, L. O., \& Adeyinka, A. A. (2007). An assessment of secondary school teachers uses of ICTs: Implications for further development of ICT's use in Nigerian secondary schools. Online Submission, 6(3), 222-229.

Ulloa-Salazar, G., \& Díaz Larenas, C. (2018). Using an audiovisual materials-based teaching strategy to improve EFL young learners' understanding of instructions. HOW Journal, 25(2), 91-112. https:// doi.org/10.19183/how.25.2.419.

United Nations (2015). Envision2030: 17 goals to transform the world for persons with disabilities. https://www.un.org/development/desa/disabilities/envision2030.html. Accessed 11 Jan 2020.

United Nations Children's Fund (UNICEF Nigeria, 2014). One in every five of the world's out-of-school children is in Nigeria. https://www.unicef.org/nigeria/education\#: :text=One\%20in\%20every\% 20five\%20of,years\%20are\%20not\%20in\%20school. Retrieved June 24, 2019.

Universal Basic Education Commission (2013). Improving access and inclusive education in Nigeria: Update on the Almajiri education programme. Presentation by Chief (Barr) Ezenwo Nyesom Wike, Honourable Minister of State for Education, to the National Economic Council, presented on 18 July 2013. Abuja: UBEC. Retrieved November 1, 2020, from http://ubeconline.com/Pre/Impro ving $\% 20$ Access $\% 20$ and $\% 20$ Inclusive $\% 20$ Education $\% 20 \mathrm{in} \% 20 \mathrm{Nigeria} \% 20 \% 20$ Update $\% 20$ on $\%$ 20the\%20Almajiri\%20Education\%20Programme\%20by \%20Hon\%20Minister\%20of\%20State\% 20for\%20E.pdf.

Valk, J. H., Rashid, A. T., \& Elder, L. (2010). Using mobile phones to improve educational outcomes. Institute of Research in Open and Distance Learning., 12(2), 45.

van Brakel, P. A., \& Chisenga, J. (2003). Impact of ICT-based distance learning: The African story. The Electronic Library, 21(5), 476-486.

Venkatesh, V., \& Davis, F. D. (2000). A theoretical extension of technology acceptance model: Four longitudinal field studies. Management Science, 46, 186-204.

Venkatesh, V., Morris, M. G., Davis, G. B., \& Davis, F. D. (2003). User acceptance of information technology: Toward a unified view. MIS quarterly, 27(3), 425-478.

Westera, W. (2004). On strategies of educational innovation: Between substitution and transformation. Higher Education, 47(4), 501-517.

Wong, L.-H., \& Looi, C.-K. (2011). What seams do we remove in mobile-assisted seamless learning? A critical review of the literature. Computers \& Education, 57(4), 2364-2381. https://doi.org/10. 1016/j.compedu.2011.06.007.

Ya'u, Y. Z. (2001). Resource control and social justice in Nigeria.\&nbsp;federalism. Resource control and social justice in Nigeria. 44-52.

Yusha'u, M. A., Tsafe, A. K., Babangida, S. I., \& Lawal, N. I. (2013). Problems and prospects of integrated almajiri education in northern Nigeria. Scientific Journal of Pure and Applied Sciences, 2(3), $125-134$.

Zamani, B. E. (2014). Differences between boys' and girls' self-efficacy, motivation and attitudes towards applying mobile devices for learning ESL. Differences, 5(37).

Zaranis, N., Kalogiannakis, M., \& Papadakis, S. (2013). Using mobile devices for teaching realistic mathematics in kindergarten education. Creative Education, 4(07), 1.

Publisher's note Springer Nature remains neutral with regard to jurisdictional claims in published maps and institutional affiliations. 